\title{
EXPLOSIVE CHARACTERISTICS OF TITANIUM, ZIRCONIUM, THORIUM, URANIUM AND THEIR HYDRIDES
}

\author{
BY IRVING HARTMANN, JOHN NAGY, AND MURRAY JACOBSON
}
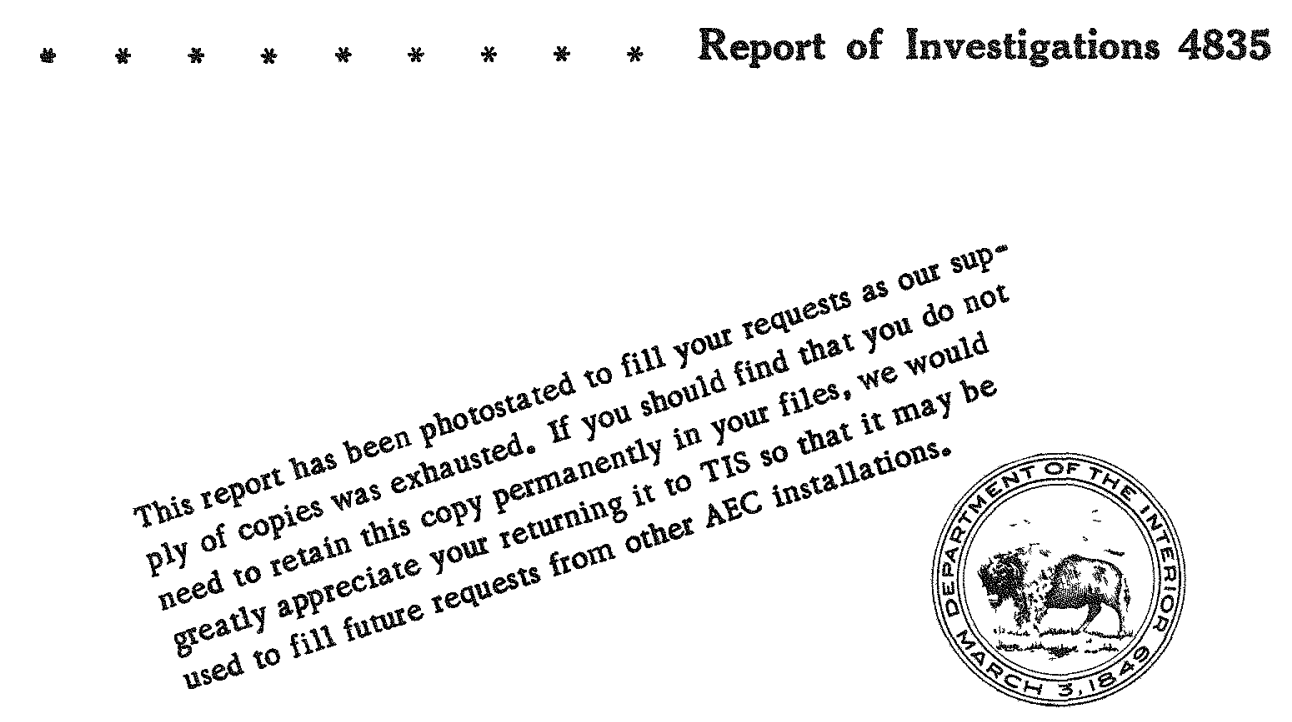

UNITED STATES DEPARTMENT OF THE INTERIOR

Oscar L. Chapman, Secretary BUREAU OF MINES

J. J. Forbes, Director

\footnotetext{
Work on manuscript completed September 1951. The Bureau of Mines will welcome reprinting of this paper, provided the following footnote acknowledgment is made: Bureau of Mines Report of Investigations 4835."

"Reprinted from
} 


\section{DISCLAIMER}

This report was prepared as an account of work sponsored by an agency of the United States Government. Neither the United States Government nor any agency Thereof, nor any of their employees, makes any warranty, express or implied, or assumes any legal liability or responsibility for the accuracy, completeness, or usefulness of any information, apparatus, product, or process disclosed, or represents that its use would not infringe privately owned rights. Reference herein to any specific commercial product, process, or service by trade name, trademark, manufacturer, or otherwise does not necessarily constitute or imply its endorsement, recommendation, or favoring by the United States Government or any agency thereof. The views and opinions of authors expressed herein do not necessarily state or reflect those of the United States Government or any agency thereof. 


\section{DISCLAIMER}

Portions of this document may be illegible in electronic image products. Images are produced from the best available original document. 


\section{EXPLOSIVE CHARACTERISTICS OF TITANIUM, ZIRCONIUM, THOR IUM, URANIUM AND THEIR HYDRIDES}

by

Irving Harimann, 1/ John Nagy, 2/ and Murray Jacobson 3/

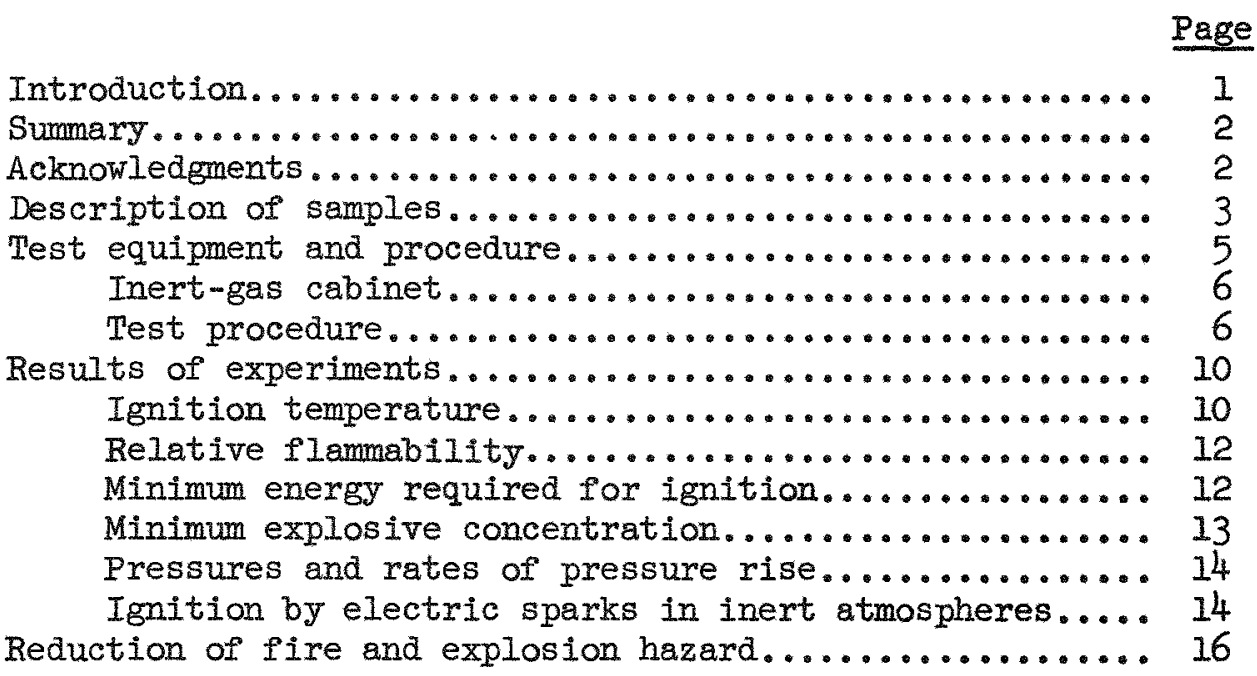

\section{IILUSTRATIONS}

Fig.

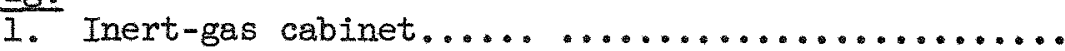

Follows page

2. Laboratory furnace and spark-ignition apparatus...

3. Apparatus for determining minimum explosive concentrations and minimum igniting energies of dust.............................. 8

4. Apparatus for determining pressures produced by

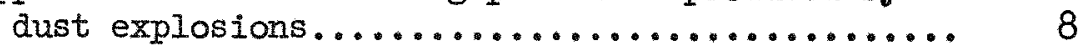

5. Pressure-time record of zirconium powder explosion in laboratory test bomb...................

I/ Physicist, Chief, Dust Explosions and Mine Experiments Branch, Explosives and Physical Sciences Division, Bureau of Mines, Pittsburgh, $\mathrm{Pa}$.

2) Physicist, Head, Mine Experiments Section, Explosives and Physical Sciences Division, Bureau of Mines, Pittsburgh, $\mathrm{Pa}$.

3/ Physicist, Explosives and Physical Sciences Division, Bureau of Mines, Pittsburgh, Pa. 
6. Spark apparatus for testing dust flamability in

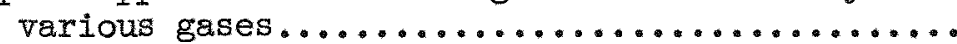

7. Minimum electrical energy required to ignite dust clouds of titanium..................... 12

8. Maximum pressure and rates of pressure rise developed by explosions of uranium............ 14

9. Maximum pressure and rates of pressure rise developed by explosions of uranium hydride...... 14

10. Maximum pressure and rates of pressure rise developed by explosions of zirconium hydride.... 14

11. Maximum pressure and rates of pressure rise developed by explosions of fine zirconium ...... 14

12. Maximum pressure and rates of pressure rise developed by explosions of zirconium.......... 14

13. Maximum pressure and rates of pressure rise developed by explosions of titanium........... 14

14. Maximum pressure and rates of pressure rise developed by explosions of titanium hydride..... 14

15. Maximum pressure and rates of pressure rise developed by explosions of thorium........... 14

16. Maximum pressure and rates of pressure rise developed by explosions of thorium hydride...... 14

17. Limiting oxygen contents in air-inert gas mixtures for preventing ignition of dust clouds by electric sparks. 
INIRODUCITIN

The results of the first axperimental stuiy by the Bureau of Mines on the explosite propertios of metal powcors wero publishoi in 1945.4/ Sinoo thet time the oxplosibility of mumorous othor industrial dusts and powders has boon invostigated. Part of this infomation has ooon yublished, $5 /$ to 15/, but nost of tho dete havo not been reloasol to urto.

This poper sumarizes the results of oxperiniuts on 22 sumplos of titeniun, zirconium, thorim, ureniun, and hycricos of thoso motels. The najor part of tho investigction was nale undor a cooporativo avreunent with tho Atomic Enorgy. Comission.

4 Hartucm, Irving, Negy, John, and Brown, H. B., Inflamejility and Ixplosibility of Metal Powders: Burecu of Mines Ropt. of Invostigations $3722,1943,44 \mathrm{pp}$.

2/ Hartacm, Irving, and Nagy, John, Inflamability and Axplosibility of Powders Used in tho Plastios Industry: Burocu of Mines Ropt. of Investigetions $3751,1944,38 \mathrm{pp}$.

6) Hartmann, Irving, and Grearweld, E. P., The Explosibility of Motal Powder Dust Clouds: Min. and Met., vol. 26, 1945, pp. 331-335.

1) Hcurtuanin, Irving, and Nagy, Jom, Hifect of kollof Vonts on Reauction of Prussures Dovolopod Dy Dust Explosions: Buxocu of Minos Ropt. of Invest1gations $3924,1946,22 \mathrm{pD}$.

8/ Hartmenn, Irving, Prossure Release for Dust Explosions: Nat. Firo Protoct: fissoc. Quart., vol. 40, July 1946, pp. 47-53.

2/ Hertmann, Irving, Rocent Rusoorch on the Hxplosibility of Dust Dispersions: Ind. Ing. Chem., vol. 40, No. 4, April 1948, pp. 75e-758.

10) Hartwann; Irving, The Explosion Hozard of Motal Powders, and Provontive Mersures: Metals Hanabook, Anoricon Socioty of Motels, 1948 ea., pp. 52-54.

11/ Hortmonn, Irving, plosion and Fire Hezerus of Corbustible Dusts: Ind. Hygiono and Toxicolog, Interscionco PuDlishers, Ino., New York, N.Y., vol. I, chap. 13, seo. 2,1948, pp. 439-454.

12) Hortmonn, Irvirig, and Nkgy, John, The Explosibility of Sterch Dust; Chen. Eng. News, vol. 27, July 18, 1949, p. 2071.

13/ Ncgy, John, Zoilinger, J. E., and Fortaon, Irving, Pressure-Relieving Capacitios of Various Diaphraga Materials: Burecu of Minos Rept. of Invostigetions $4636,1950,15 \mathrm{pp}$.

14/ Hartmonn, Irving, Dust Explósions: Marks'Mochanical Hngineors' Hohdbook, 5 tin ec., 1950, pp. 795-800.

15/ Hartwanr, Irving, Coopor, Austin R., Jnd Jocobson, Murray, Rocent Stucies of tho Explosibility of Com Starch: Bureru of Mines Ropt. of Investigations $4725,1950,9 \mathrm{pp}$. 


\section{SUMMRI}

The investigetion disclosod that dust clouls of the powders in air constitute sovere potential oxplosion hazaris. Some of tho samples were pyrophoric; theso wero storod and preparal for tosting in a holiuis atuosphore in a speolal cabinot.

Layers of uranium, urantur hydxide, end thorium hydrido ignited spontanoously at room temperature within a few minutos after oxposuro in air. Iayors of the othor powiders ignited in air at tomperatures of $100^{\circ}$ to $540^{\circ} 0$. Layors of sovereI dusts ignited at elovated temporatures in carbon dioxido and in nitrogon.

/Dust clouds of upentuan, upentum hydxido, and zipeoulum ignited at roon tomporaturo irmodiately upon dispersion." Clouls of the other powlers ignitod in air at 2600 , to $5900 \mathrm{c}$. Sono dust clouks also ignited at olevated temperatures in carbon dioxilo. HIl dust olouds covld bo lgnited in air by weak eleotrical sparks. In the prosence of a high-voltege eloctric sporit, dust clonis of

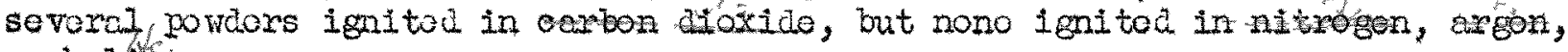
or hezlute.

The energy required to ignite thin layers of the powiers in air by electrical-condensor afschargo sparks rangol from less than 1 ulderojoule to 3 mililjoules, and the igniting encrgy for dust clouds ranged from 3 to 200 nilitjoulas.

Tho lower explosive Iinits of dust clouds in air rungod frou 45 to 300 nilitgresus pot litor. (approxinate $1 \mathrm{y} 0.045$ to 0.300 ounco par culjo foot). Explosions, of dust clouds in a laboratory tost boub prolucod prossuros as high as 127 pounds por squere inch (tho cbbreviation p.s.i. will bo usod for this" unit); avorago rates of prossure riso up to $5,100 \mathrm{p}, \mathrm{s}$. 1 . por second and roximum

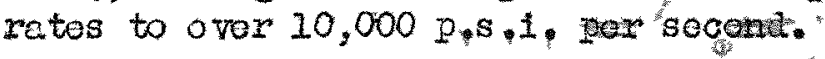

A thin surfece coating of compor on titentiving and zixconity powlors reduced the ignition sensitivity sonowhat; but, upon igition, dust clouds of the comper-conted powlers protuced explosions that were nearly cs strong as those of the antreatod powders.",

The study indicates the advisabllity of processing gha hanling sevoral of these powjors whon in the ary stato under hollus or arbon ges./2.h.

\section{ACRNOULWDCMIJUS}

Tho cooperative agrocuent with the Atoule Bergy Comission was arranged

- by Edward J. Kehoe, chief, Fire and Accijent Bronch, Eeolth and Safoty Divis ion, of the Wow York office of the A. I.C., and Dx. Bexnard Lewis, chief, Bxplosives and Physical Sciences Division, Buroau of Mines. Nine of the powiers used in the study wore preparod for tho A.E.C. by Sylvania Electrio Products Co., Bayside, Long Island. E. J. Kehoo, F. I. Bronnigan, and Paul Klovin of the New York office of H.E.C. and Dr. Bcmard Kopelnan of Sylvania cooperatod wost helpfully with the Bureau of Mines throughout this phase of the work.

$$
+2305
$$


4. fow selasles of titanium and zirconiw and one hyuricie of each woro obtained through the courtesy of Mctel Hydriwos, Inc., Beverly, Mass.

Much of the laboratory test work was done by Austin R. Cooper, physical science aide, and Roger $P$. Williams, laboratory mechanic, Dust Explosions Section, Bureau of Mines.

\section{DESCRIPTION OF SAMPLES}

The test samples were numbered in the orwer of their receipt at the laboratory. The samples will be lesignated by these numbers in this report.

Most of the powders were receivod in 1-2ound lots; this quantity is usually enough to conduct all of the tests. Some semples that arrived in the dry state were shipped in air, others were shipped dry under argon gas or in an evacuated. container, and a few ome as a sludge under a liquid.

A doscription of the appoaranco, analysis, and particle-size distribution of the samples follows. Unless otherwise notod, the samples were tosted in the finenoss in which thoy were receivod.

Titanium. - Seven titanium powders, including two copper-ooatcd samples, wore testod.

15. 740. - Roceived in ary stato; daxk-gray angular perticlos. Spoctrographic analys is indicated 2 to 3 percont motallic immuties. Ninetynino percent of the particlos were finor than 100-mesh (Tyler-sievo scalo), 68 porcont finer than 200-mosi, and 62 percont iner than $270-$ mosh. Explosibility tosts wero made on the powser in the fineness in which it wos recoivod, and edditional tosts woro mado on the fraction through 200-mosh. This is the titanium sample roported in Report of Investigations 3722. For tho sake of complotonoss, the information is includod in this roport.

IF. 864. - Recolvod in dry stato. All portiolcs woro fincr thon 200-mosh, and 50 percent wero roportod to bo finor than 325 -mosh ( 45 microns). Analys is was given as 68.67 percent T1, 8-9 percent AI, 2.4-2.8 percent Si, 0.05 peroont C, 3-4 perocnt Fo, 1-1.25 poroont ou ond the belanoe alumina $\left(\mathrm{Al}_{2} \mathrm{O}_{3}\right)$.

No. 1552 . - Received in moistoned condition. A portion of the scmple wes drlod at $75^{\circ} \mathrm{c}$. for 24 hours, givine off 22.7 porcent mo is ture. The tosts wero made on the dried powder after it ncd beon possod through a 200-nosh sieve to break up agglomoretion. The particle-size distribution is given in table 1 , together with bata for 10 othor samples. Chomical analys is was reported to show 96.3 percent Ti..

No. 1556. - Recelvod in ary stato. Inis is a spociclly proparod samplo (supposedly from the same batch as 1555) with a thin coppor coating on the surfece of the powder particles. Application of tho coating and hoat treatmont of the powdor are in on oxporimental stage. Analys is was roported to show 88.2 porcont $11,7.0$ percont $\mathrm{hi}$. Assuming sphorical particlos of 10 microns wimcter, a coppor contont of 2 percont was considcroc to roprosont a thicknoss of copper coating of 1.6 millinicrons. 
No. 1605. - This is an untroatod titanium powder similax to 1555. The sample was reoeived in dry state under argon gas. It was used only for a few tests.

Mo. 1606. - This powder was takon fron the sene lot as 1605 , but tho particles contained a surface cocting of copper. (Soo also 1556). It was reported to contain 85.6 porcont Ti and 12.7 poroont $C u$. The sample was recelved dry under ergon.

No. 1648. - Roceived in dxy state under argon gas. The netal was ropoxted to contain 0.08 porcont hydrogen, 0.82 porcont oxygon, and 0.062 pexeent nitrogon. The averago partiolo diometer dotemined by the subsieve sizer was given as 10.5 microns. The particle-sizo distribution by the photolometor method was roportod to bo as follows: 24.0 percent, by wolight, 0-10 miorons; 40.3 percont, $10-20$ microns; 35.7 percent, 20-40 microns; averego, 17.8 microns.

Titanium Eydride (TiH2). - Tho following two somples were tested:

No. 1428. - Gray powder, recelved in dry condition. Reportedy, over 98 percent of the particles were finer than 325-mesh, with the greater portion in the 10- to 25-micron range. The composition was reported as 95.0 percont $\mathrm{TI}, 3.78$ percent $\mathrm{H}_{2}, 0.1$ percent $\mathrm{Ca}$, and 0.1 percent $\mathrm{C}$. No. 1649. - Recelved dry under argon gas. Analysis wes reported to show 2.83 percent $\mathrm{H}_{2}, 0.24$ percent $\mathrm{O}_{2}, 0.071$ percent $\mathrm{N}_{2}$. Although this hydride contained only 70 percent of the theoretical hydrogen for THH2, it was said to behave in many ways as a fully hydrided material. The avorage particle diametex by subsievo-sizer analysis was given as 4.9 microns. Photelometer measurements were reported to give 88.1 percent partioles between $0-10$ mierons; 10.0 percent, $10-20$ mierons; 1.9 percent, $20-40$ microns; average, 5.2 miorons.

Ziroonium. - Seven zirconium powders, including one copper-coated sample, wo ro tas ted.

No. 745. - Gray powder; roceived in a moistened state as a sludge. The metal contalned 2 to 3 poroent metallic impuritios. Tho particles were - reported to be finor than 325-mesh. Tho tast data for this sample wero roported in Report of Invostigations 3722 .

No. 1028. - Received as a sludge. Apparently finer than 325-mesh; particle-size distribution not known. This sample was reportedly taken from a wooden keg in which zircomium is stored under water before it is used for spraying plates and other perts of vacuum tubes. No. 1029. - Received as a sludge from same source as 1028. This powder represents the fine particles that are camied away in the air stream of the spraying room.

No. I557. - Received in dry state. Reportedly contains 98.7 percent Zr. No. 1558. - Received in ary state. This sample was from same batoh as 1557 but had a thin surface coating of copper (see remarks for 1556). Reported to contain 90.5 percent $\mathrm{Zr}$ and 4.4 percent $\mathrm{Cu}$.

Ho. 1632. - Received under water. Reported to contain 3.0 percent $\mathrm{O}_{2}$. The average particle diameter by photelometer measuroments was given as 3.3 microns.

No. 1633. - Rocelved dry under argon. The material was said to contain 0.29 percent $\mathrm{O}_{2}$ and 0.025 percent $\mathrm{N}_{2}$. Average diameter by photelometer measurements was given as 17.9 mforons. This zirconium was prepared. fromits hydride (1627). 
Zirconium Hydride $\left(\mathrm{ZrH}_{2}\right)$. - Tho following two samples of hydride were testod: No. 1429. - Received in dry state, Ovor 98 percent of the powder reported to be finer than 325-mosh, with the major portion of the particles botween 10-25 microns. The composition was reported as 93.6 percent $\mathrm{Zr}, 2.08$ percont $\mathrm{H}_{2}, 0.18$ percont $\mathrm{Ca}, 0.07$ porcont Fo, 0.01 percent $\mathrm{C}$, 1.0 percent Hif, 0.70 porcent $\mathrm{SiO}_{2}$.

No. 1627 . - Received under argon. Analys is reportod2y gavo 0.19 percont $\mathrm{O}_{2}$ and 0.022 percent $\mathrm{N}_{2}$. Averago partscio diamotor by photolometer moasuromont was 4.7 microns.

Thorium.

15. 1652. - Derk-gray powder, rocoived in an ovacuatod pyrox bulb. Roportod to contain 0.032 percont $\mathrm{H}_{c}, 1_{0} 20$ poreunt $\mathrm{O}_{2}$, and 0.19 porcont $\mathrm{N}_{2}$. Averago particlo diamotor by subsicto sizor givon as 7.2 microns and by photolometor as 7.4 microns.

Thorium Hydri do (ThH $)$.

No. 1653. - Groenish-gray powdor rocoived in an cvacuated pyrox bottle. Analys is roported to show 0.94 percont $\mathrm{H} 2,1.07$ porcont $0_{2}$, and 0.16 porcont $\mathrm{N}_{2}$. Theorotical hydrogon porocntago of ThH is 0.86 . Avcrago particle diametor by subsiove sizer was given as 3.8 microns and by photolomoter moasuromont as 2.9 microns.

Uranium.

No. 1625, - Silvor-gray powder, rocolvod undor argon. Whon tho samplo arrivod, tho uppor portion of tho powdor had beon considorably darkonod. No important difioronco was observod, Datweon the oxplosibility of the light and the darkonod portion. Anelys is was roported to give 0.07 percont $\mathrm{O}_{2}$, and 0.008 porcont $\mathrm{N}_{2}$. Avorago perticlo diameter by photolomoter moasurcuent 10.8 microns.

Uranium Hyduido (UH3).

150. 1626. - Dark-gray powder, received undor argon. No chomical analysis Wes roportod. Avorage particlo diamotor by subsiove sizor was 3.6 wicrons and by photolometor, 3.3 microns.

Moro dotailed information of the particlo-size distribution of 11 of the above powdors is givon in tablo 1 .

\section{TIST EQUIPMENT AND PROCEDURE}

Tho oquipment and test procodure wero, for the most part, similar to those described in Roport of Investigations 3722 (soe roferonce 4/). Modifications and improvonents medo since the original construction will bo pointcd out. Tho dry powders wore tostod in the finonoss and form as received. To propare tost samplos frow tho powdors recoivod os sludge, small quantitios wore washod with alcohol, and the oxcess liquid wes drained off; the rosulting powdor was driod by slow hoating. As sone of the powders wore pyrophoric, great caro was takon to provont fires during storago and handing of tho dry samplos. They wore kept oithor in evacuated containors or under inort ges. 
TABLE 1. - Particle-size distribution of powders

\begin{tabular}{|c|c|c|c|c|c|c|c|c|c|c|c|}
\hline \multirow{2}{*}{$\begin{array}{c}\text { Finonoss, } \\
\text { microns }\end{array}$} & \multicolumn{4}{|c|}{ Porcont by wolght] } & \multicolumn{7}{|c|}{ Porcent by wolghtel } \\
\hline & No. 1555 & 1556 & 1557 & 1558 & 1625 & 1626 & 1627 & 1632 & 1633 & 1652 & 1653 \\
\hline $0-1$ & 27 & 28 & 15 & 23 & 4.0 & 10.6 & 10.6 & 5.9 & 2.1 & 2.8 & 3.5 \\
\hline $1-2$ & 29 & 20 & 24 & 31 & - & 27.7 & 20.1 & 19.2 & - & 6.5 & 10.0 \\
\hline $2-3$ & 22 & 15 & 23 & 23 & 2.0 & 17.5 & 14.2 & $27 \cdot 3$ & 1.5 & 13.9 & 28.2 \\
\hline $3-4$ & 10 & 12 & 13 & 12 & 3.1 & 11.9 & 23.5 & 18.7 & 1.2 & 11.6 & 19.3 \\
\hline $4-5$ & 5 & 11 & 10 & 6 & 5.0 & 8.5 & 6.3 & 14.3 & 1.5 & 10.9 & 14.3 \\
\hline $5-6$ & 2 & 4 & 4 & 1 & 4.8 & 10.7 & 7.7 & 8.5 & 2.8 & 8.3 & 9.6 \\
\hline $6-8$ & 2 & 5 & 7 & - & 14.1 & 10.3 & 2,4 & 3.3 & 5.0 & 14.0 & 8.7 \\
\hline $8-10$ & 1 & 2 & 2 & 3 & 16.3 & 2.2 & 1.8 & .9 & 7.0 & 7.4 & 4.4 \\
\hline $10-12$ & 1 & - & - & $=$ & 15.6 & .6 & 3.8 & 1.7 & 7.6 & 5.6 & 2.0 \\
\hline $12-14$ & - & 2 & - & - & 13.0 & - & 2.6 & - & 7.8 & 6.2 & \\
\hline $14-16$ & Trace & - & - & - & 9.8 & - & 2.2 & - & 8.5 & 4.2 & - \\
\hline 16 & - & - & 1 & - & 6.0 & - & 3.7 & - & 118.3 & 4.5 & - \\
\hline 30 & - & & - & - & 4.9 & - & 1.3 & - & 26.8 & 4.1 & - \\
\hline $30-40$ & - & - & - & - & 1.3 & $=$ & - & - & 10.0 & - & - \\
\hline
\end{tabular}

If By microscopic analysis.

2/ By photolonoter analysis. 


\section{Inert Gas Cabinot}

During the recent investigation or the lest nine powders, a special. cabinet was constructed for handling and storing. The cabinet consists of a main chamber (approximately $24 \times 24 \times 30$ inches) and an airlock or transfer chamber $(6 \times 6 \times 8$ inches). The construction is of $1 / 4-$ inch steel welded at all seams. Figure 1 is a general view of the cabinet. The main chamber has a glass viewing window, 3/4-inch thiok and 12 inches square, in the front wall. In the back wall is a 20-inch square vent sealed with a reinforced, plasticimpregnated, cloth diaphragm. The purpose of this vent is to relieve pressure in case of an cccidental explosion in the caininot. The airlock is welded to the left side of the chamber; the doons of the sirlock close on rubber gaskets, forming airtight seals. Equipment in the main chamber incluces an analytical belenoe, a fluorescent Iight, and tools and jars for working with tho powders. All manipulations in the cabinet are made by an operator vearing special gloves, which are sealed to portals welded to the main soction.

In designing tho oquipment, provisions wore made for evacuating the main chamber and airlock and flliing thom with highly purifiod helium gas obtained from the U. S. Holium Production Co., Amarillo, Tox. Gas and mass spectrograph analyses showed that, initially, tho systom rad to be ovacueted and Ilushod with helium three times to attain tho desired inort etmosphone. The holium pressure in the cabinot at all timos was maintainod at betwoon 1-1/2 and 3-1/2 ounecs. per squere inch goge by means of a sonsitive prussuro switoh and a solonoid valve. A mercury chock valv was placed in the system to prevont excoss pressuro.

Eollowing recelpt of a smple, tho original containor was placed in tho inert-ges cabinot, and a small quantity of powdor was transforrod in the incrt atmosphere to a 2-ounce scrow-top jar. The original container was resealed corofully and removea from the cabinet for storago until it was nocded again. The test somplos were woighod in the cabinet and romoved only a fow minutes bofore actual tosting.

\section{Tost Procooure}

Several tests wero porformed on tho dusts to jetomino tho ease of ignition and the various factors that influence the explosion hazard. A brief outline of these tests follows:

The ingition tompereture of the dust clouds was cetorminod in a vertical, electrically heatod cylindrical-tube fumace, the top of which is connected to a sinall brass chmber, or dust boat, into which $a$ weighod omount of dust can bo placed. The dust wes projectod by compressed air downward through the furnace, and ignition wes indicated by the appecrance of a flane at the open furnace mouth at the bottom. The electrio heating circuit of the furnace includos an automatic thermostatic control. Tho lowest fumaco tomperature at which ignition occurs was considored to be the ignition temperature of the dust cloud. The furnace is show on the left in figuro 2 . 
The furnace was used in a modifiod form to dotermine the ignition tomperature of dust layers. In theso tests the top was open, and a smoll anount of dust was pleced on an aluminum oxido disc at tho conter of the furnaco. A slow strom of air flowed upwerd through the fumace and around the heated dust layor. Tho lowest tomporature at which tho dust ignites or glows strongly, or at which its tonporaturo shows a suddon repld riso, was considorod as the ignition tomporbturo.

The proceduros for detomining the igntion temporatures of dusts in gases othar than air wero similar, but before tho dust sample was plccod in the boat or on the alminum oxide disk tho ontire sys tom wes flushod thoroughly with the gas to be investigetod, and the dust was proteoted from air throughout tho tost.

The rolative flammability of tho powdor denotes the omount of inort. dust, exprossed as the percontago of tho total mixture, required in adnixture with tho powder to prevent ignition when the mixture is blown through the cylindrical furnoco under 2 standard sot of conditions. This systom of rating was originally dovelopod for cocl dusts and is significant becauso it gives, a measure of the amount of rock aust roquired to provent the propagetion of coal dust explosions in mines. The inort dust used in the laboratory tosts was calcined fullex's earth. The relativo flamability of seworol powders was detoritinod also in a second test in which a high-voltage, low-energy, continuous-induotion spark wes substitutod for tho hoatod fumaco as an ignition source. The pyrex spark tubo, with a goosoneck-shapod top ocn be soen on tho right noar tho center of figuro 2 .

To moasure the minimuri cnorgy requirod for ignition of dust cIouds oxporiments were conducted with olectrical-condenser dischargo spexks. A condenser was charged to a definite potenticl, and the fomction of the dust cloud in a cylindrical lucite tube was synchronized with tho discharge of tho condonser through the prinary winding of a iuminous-tubo step-up transfomer. Tho e.r.f., induced in the secondary circuit of the transfomer, produced a spark betwoon the olectrodes in tho dust cloud within the luoito tube. Condensers of different capecitios were tried to ind tho weakest spark that would ignite the sample. Higure 3 shows the epporatus usod in these tests. The cylindrical Iucite tube (I.D. 2.75 inches, longth 12 inchos) is show on a stand noar tho center of the Ilgure. To the right of the tube aro a small compressed-atx tank and e magrotic valve, through which the air flows to the botton of the Iucito tube and disperses the dust apward. To the left and silghtly in back of the tube is tho luninous-tubo transformer. On the left of tio figure is a box containing the electronic tining and control circuits. A variabie condensox can be seen on top of this box.

In the experiments on the ignition of dust layors, the condonser was aischargod, without stop-up in voltago, directly through the spark gap betweon a point electrode and a grounded metal disk on which the dust was placed.

The minimum explosive concentration or lower explosive limit of the dust clouds was found by determining the lowest average dust concentration in the lucite-tube apperatus in wich a dust ignited and propageted Ilame throughout the-aloud, as indicated by the development of enough pressure to break the weak 4539

$$
\rightarrow 201+8-
$$


fliter-paper diaphragn at the top of the tube. The igniting source used in these experiments is a high-voltage continuous electrical-induction spark having an average power of 24 watts.

The mertimum pressure and the retes of pressure rise developod during a dust explosion indicate. the structural damage that might result. They also fumish some information on the vent roquirerients in buildings or in equipment where explosions nay occur. The appezatus used for measuring pressures and ratos is shown in figure 4. It consists essontially of a chromium-plated cylindrical steel test bomb (1.23 1iters) in which the dust cloud is formed and 1 gnited and a recoraing pressure manometor nounted above the bomb. The manometer is of the elaphragm type; tho deflection of the diaphragn is magnified by an optical system. A pressure-time record of the explosion is obtained on a photo graphic film nounted on a rotating dmm.

A weighed amount of the dust to be tested was placed into a specially. designod brass cup at the bottom of the bomb. This dust. was dispersed upward by the sudden release of a smell volumo of compressed air. Originally the. compressed air was placed in a 1.3-1itor contaliner at 8-12 p.5.i. prossure. Rocont oxporiments with many dusts, including the comparativoly heavy metal powders, have show that better dust clouds are formed end stronger oxploslons produced if the air used for dispersion is roleased from a 50-cc. cylinder at a pressure of $100 \mathrm{p} .5 .1$. This arrangement was used in most tosts in this investigation.

Figure 5 is an enlargement of an actual prossure-tina record. It 1 llustrates the nanner in which the prossure and the rates of pressure rise are computed from the film record. Iho distance betweon successive dots on the horizontal time axis represents an interval of $1 / 120$ second. As can be soon on tho flgure, following ignition of tho dust (at point A) the prossure rises slowly at first, then very rapidiy for a time ( $D$ to F), ana again less rapialy, roaching a meximum value at point $C$, after which it sterts to decroaso.

The use of inert gas to reduce or eliminato the hazerd of dust explosions is fainly comon in some industrial processes whero highly explosive dusts or powders are handled. In this investigation, the ignition temperatures of dust clouds and of dust layors were determined in commercially puro carbon dioxide and in nitrogen; tho ignitibility of dust layers was studied et $850^{\circ} \mathrm{c}$. in a 50-50 mixture of air and holium. In addition, a sorios of nixtures of aircarbon dioxide, air-nitrogen, air-argon, and eir-holizm, wes propared and tosts wero made in the induction-spark apparatus to determine the 1 initing mixtures that would prevent ignitions and oxplosions of the dust clouds. A schomatic diagram of tho apparatus is shown in figure 6 .

Beiore each test the entire system was flushed thoroughly with the gas mixturo, and the spherical glass bulb was fililed with the gas for dispersing the dust from the dust boat through tho spori tube. A. wator manometer indicated. the rate of llow of gas that was bled slowly through tho spark tube during the entire test. 
Those engaged in handling the powiers and in the actual experimental work wore protective gloves; all operations were performed in such a manner as to protect personnel against dust and fumes. All ignition and explosion tests were made under closed, well-ventilated hoods, and other necessary safeguards were taken to insure satisfactory health conditions for the experimenters.

\section{RESULTS OF EXPERTMENTS +}

The data obtained in the explosibility tests are recordod below in tables and Ifgures, which are largely self-explanatory. Unusual efiects noted in the work and the results of special tests will be discussed briefly.

\section{Inition Temperature}

The ignition temperature of dust clouds and of undispersed dust layers, determined in air, carbon dioxice, and nitrogen, is show in table 2 . In tests with Just clouds, the dust (usvally 1 gram) was projoctod rapidiy through the furnace, passing through the hot zone in less than 1 sccond. In tne tests with undsporsea layers, tho dust was kopt at the center of the hot fumace for soveral minutes (up to 15 minutes if no ignition ocoured).

When samples of uranium, uranium hydrido, and sevoral zirconium powders were dispersed through the fumace at room tomporature, (approximately $200 \mathrm{c}$. ) strong ignitions resulted. In this ruspoct zirconium samplo 1635 did not bchave liko othor untreated zirconiums, and the dust cloud in air did not ignite below $3500 \mathrm{c}$. Coyper-coatod zirconium $1558 \mathrm{had}$ a minimum ignition tomperature of $480^{\circ} \mathrm{C}$, comparod with $20^{\circ} \mathrm{O}$. for untreated samplo 1557 from tho samo batch. Dust clouds of coppor-coatod titanium 1556 ignitod at approximatoly the samo temporaturo as untroatod samplo 1555 from the same batoh, but coppor-coatod titanium 1606 ignitod at a tomperaturo about $1000 \mathrm{C}$. higher than untroated samplo 1605 from tho samo batch.

Dust clouds of four of tho nine powders tosted in an atmosphore of carbon doxide ignited, but nono of the dust clouds tosted in nitrogon ignited.

No ignitions resultod with 1 to 3 grams of uranium hydride exposed in layers in air at room tomporaturo; I gram of the powar ignitod at minimum tomperature of $1100 \mathrm{c}$. When 5 grams of uranium hydride was placod on a watch glass at room tomperature, the surface darkonod immediatoly and a few bright spots appeared; within a fow minutos a slight popping noise was hoard, a Jellow flame was seen over the surface, and the ontire mass assumed a dull-red glow; tho residue was black. Throe grams of thorium hydride oxposed in air at room tomporaturo ignitod within a fow minutes; the ignition was charecterized by an intonse Jollow glow; tho rosidue was a powdory white dust. It is quite possible that other metals or hydrides might ignite spontanoously if largo quontititos of the powders wero exposod to air. In fact, uranium powder did ignite whon a pilo of about 300 grans wes properea for disposal.

$$
\text { 0723-019 }
$$




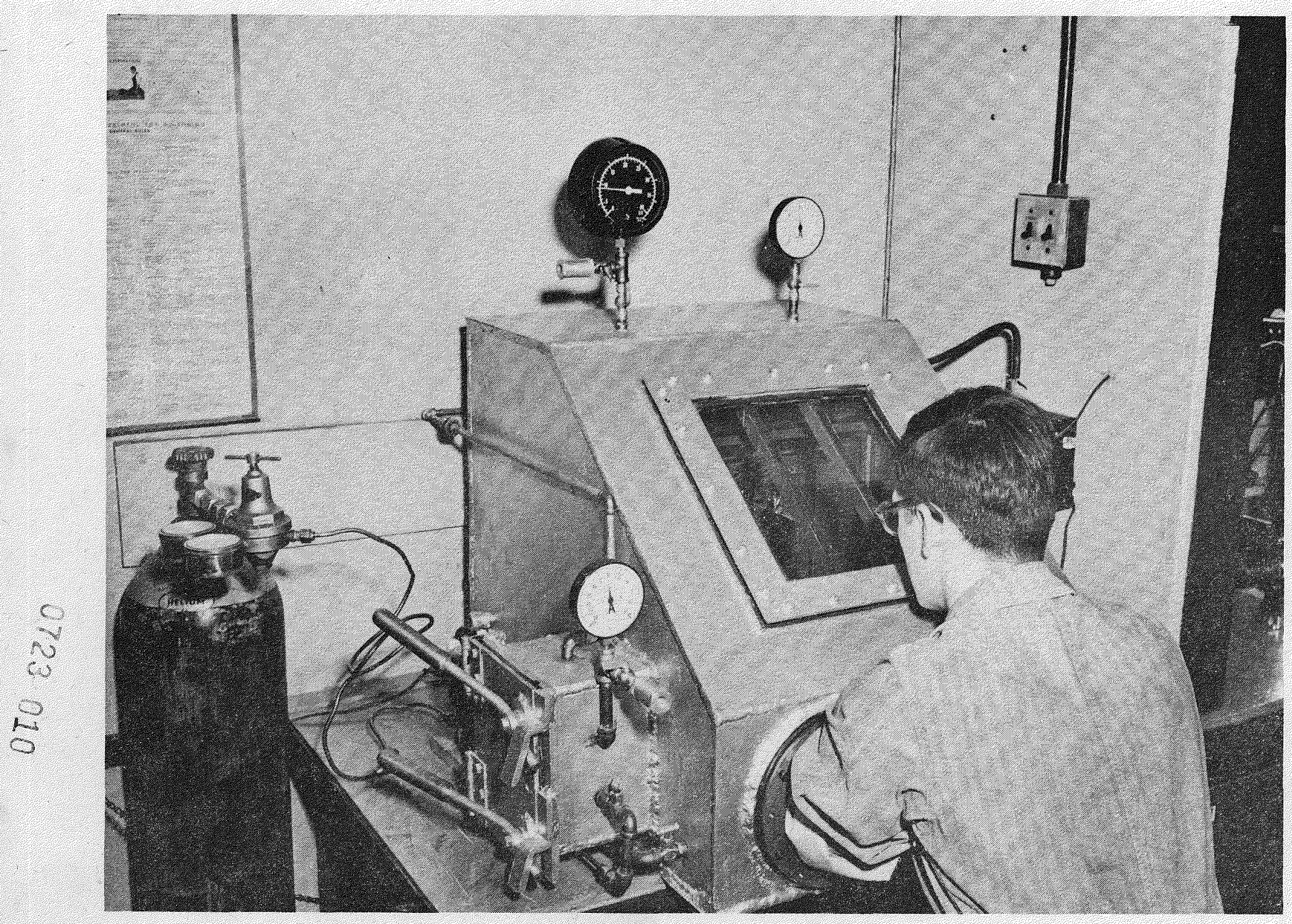

Figure 1. - Inert-gas cabinet. 
TABLE 2. - Innition tomporaturo and relativo flemability of powdors

\begin{tabular}{|c|c|c|c|c|c|c|c|c|c|c|c|c|c|c|}
\hline \multirow[b]{2}{*}{ Sanp 10} & \multicolumn{5}{|c|}{$\begin{array}{l}\text { Ignition tomperature } \\
\text { of dust clouds, }{ }^{\circ} \mathrm{C} . \\
\end{array}$} & \multicolumn{5}{|c|}{$\begin{array}{l}\text { Ignition tomporaturo } \\
\text { of dust layors, }{ }^{\circ} \mathrm{C} \text {. }\end{array}$} & \multicolumn{4}{|c|}{$\begin{array}{l}\text { Ruletive flammability } \\
\text { porcont inort }\end{array}$} \\
\hline & Air & $\mathrm{CO}_{2}$ & & Ne & & Ajz & & $\mathrm{CO}_{2}$ & & $\mathrm{Ne}$ & & $\begin{array}{l}\text { In furnac } \\
\text { at } 700^{\circ} \quad\end{array}$ & & $\begin{array}{c}\text { Spark } \\
\text { apporatus }\end{array}$ \\
\hline $71-740$ & 480 & - & & - & & 460 & & 680 & & - & & 52 & & 77.5 \\
\hline 864 & 530 & - & | & - & & 470 & 1 & - & & - & & 25 & & 37.5 \\
\hline 1555 & 470 & - & & - & & 480 & 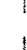 & - & & - & ! & 90 & & 85 \\
\hline 1556 & 460 & - & 1 & - & & 430 & 1 & - & & - & & 90 & & 85 \\
\hline 1605 & 480 & - & $t$ & - & & 460 & 1 & - & i & - & 1 & - & & - \\
\hline 1606 & 590 & - & 1 & - & & 380 & & - & & - & $i$ & - & & - \\
\hline 1648 & 1330 & $n \cdot i * 1$ & & n.t. & & 510 & 1 & 550 & : & 760 & 3 & - & & - \\
\hline TiHe1428 & 480 & $1 \quad-$ & $!$ & - & & 540 & 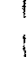 & - & & - & 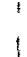 & 80 & & 70 \\
\hline 1649 & 440 & n.1. & 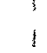 & $n . i$ & & 500 & 1 & 720 & & 750 & & - & & - \\
\hline $2 x-745$ & 202 & - & & - & & 210 & 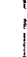 & 560 & & 530 & & $90+$ & & $90+$ \\
\hline 1028 & 20 & - & $i$ & - & & 260 & i & - & & - & 1 & $90+$ & t & $90+$ \\
\hline 1029 & 20 & - & ? & - & & 290 & 1 & - & & - & & $90+$ & & $90+$ \\
\hline 1557 & 20 & - & 1 & - & & 220 & 1 & - & & - & & $90+$ & & $90+$ \\
\hline 1558 & 480 & - & 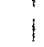 & - & & 320 & i & - & & - & & 90 & $i$ & 90 \\
\hline 1632 & 20 & 650 & & n.1. & & 190 & 1 & 620 & & 790 & & - & & - \\
\hline 1633 & 350 & n.i. & , & n.i. & & 300 & 1 & 710 & & n. 2. & & - & & - \\
\hline $2 \times{ }_{2}-1429$ & 350 & - & & - & & 270 & 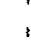 & - & & - & & 85 & 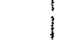 & 80 \\
\hline 1627 & 430 & $n+i$ & & $n . \dot{1}$ & & 340 & 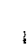 & 650 & ; & n.i. & 3 & - & & - \\
\hline Th-1652 & 270 & 740 & & n.i. & & 280 & 1 & 420 & & 500 & ' & - & & - \\
\hline ThH $2^{-1653}$ & 260 & n.1. & & n.i. & & 20 & & 340 & ' & 330 & & - & $\vdots$ & - \\
\hline$U-1625$ & 20 & 560 & & n.i. & & 100 & & 350 & & 410 & & - & & - \\
\hline $\mathrm{UH}_{3}-1626$ & 20 & 720 & & n.i. & & 20 & 1 & 360 & & 210 & & - & 1 & - \\
\hline
\end{tabular}

I] n.i. denotos no ignition at $850^{\circ} \mathrm{C}$, the highost temperature usod in thoso tests.

2/"20"in this tablo donótes ignition at room touporaturo, approximatoly 2000. It is probablo that in dust clouds this ignition was causod by an eloctrostatic dischergo within the cloud, although frictionel hoat doveloped during the movoment of the powder may have boon a contributing factor. Ignition of dust layors of $\mathrm{ThH}_{2}$ and $\mathrm{UH}_{3}$ at room tomporaturo indicatus thoir highiy pyrophoric charcetor.

The ignition tomperaturo of an undisporsed laycr of copper-conted zirconium (1558) was $1000 \mathrm{C}$. higher than for an untranted zirconium sample (1557) Iroul the scmo batch. In contrast to this, both copper-coated titanium samples ( 1556 and 1606) had lower ignition tomperaturos than the corresponding untreated titanium powdors (1555 and 1605).

At clovated tomperaturos, dust layors of all saplos tos tod in carbon dioxide and of all oxcopt two of the somples in nitrogen ignited.

Spall layers of the nine metal potrans most recently tosted were exposed at $8500 \mathrm{C}$. in an atmosphere of 50 pereont air and 50 percent helium, by volume. All dusts igited within a fow minutos. Tho tost was not made gt other tomperaturos. 
The results of the relative flamability tests conducted on many of the powders are rocordod in the last two columns of table 2. The Iowest values were obtained for dust clouds of the relatively inpure titanium powder, 864, followed by tho comparatively coarse titenjum, No. 740. All other powders tested required a mixture of at least 70 porcent, and at most $80-90$ porcent, inort dust to prevent ignition and suppress flane propagation. A value of 904 percont indicatos that more than 90 percont inort dust was required for this purpose.

\section{Minimum Energy Requirod for Ignition}

Tablo 3 contains tho data from the ignition tests with condensor discharge sparks. The onorgy value for dust clouds ranges from 3 to 200 millijoules; that for dust lajers ranges from less than 1 microjoulo to 3 millijoulos. In tests with dust clouds, considorable proliminary work was roquired to find tho optimum conditions for ignition. Tho minimun igniting onergy deponds, anong other factors, on the particlo size of the dust, tho concontration of the dust cloud, the characteristics of the igniting circuit, and the tining of the igniting spark relative to the fomation of the cloud.

$$
\text { TABLE 3. }-\frac{\text { Minimum eloctrical lgniting energy and }}{\text { lower explosive limit of powdors }}
$$

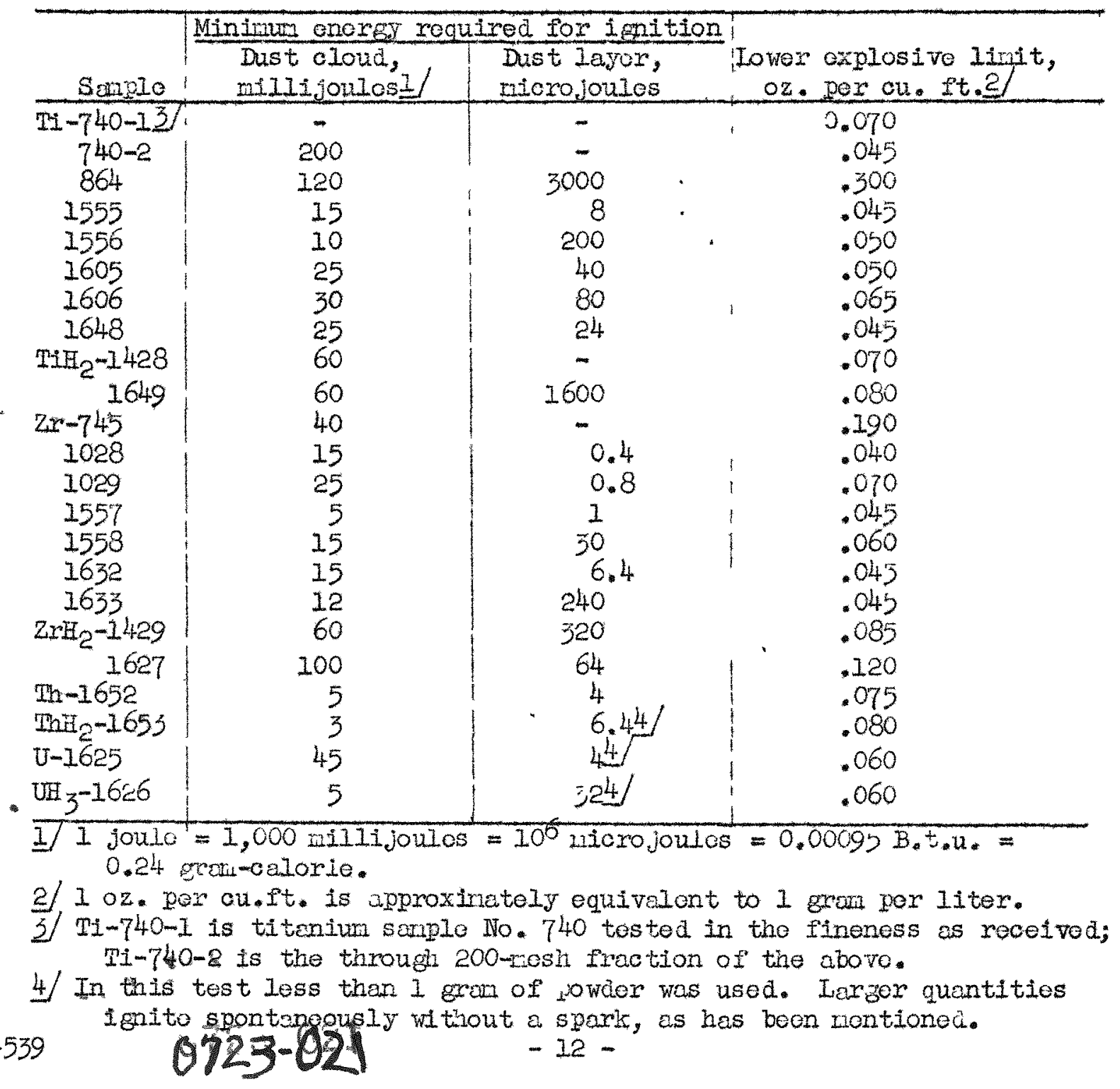




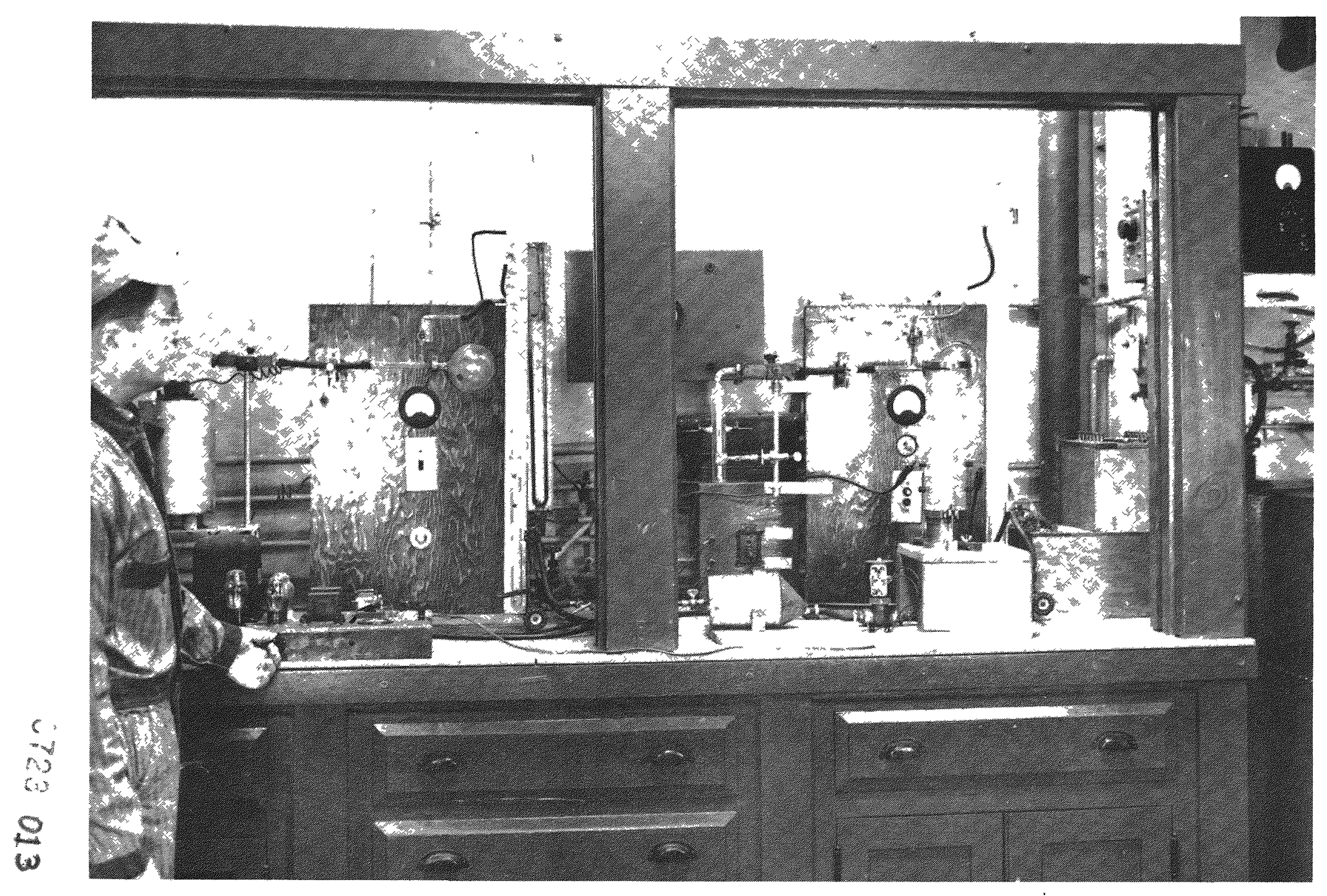

Figure 2. - Laboratory furnace and spark ignition apparatus. 
Figuro 7 shows the effoct of dust concontration on the aininum Igating onergy of dust clouds of titantun pawdor 1648.

The minimun encrgy value for samplos $1555,1556,1557$, and 1558 , show In tablo 3, wes detemined indediately after ronoval of tho powders from the original containers ( $\mathrm{Ii}-1555$ wos driod first). At the saio tive portions of those powdors wore exposed in the laboratory air for 6 wooks, out of alrect sunlight, to detemine the offoct of oxidation or othex surfoce changes. Aftor this exposure, the samples again were subjeoted to uinimumenergy tests. Table 4 shows a comporison of the data.

TABIE 4. - Erfoct of exposure in air on igniting energy of powders

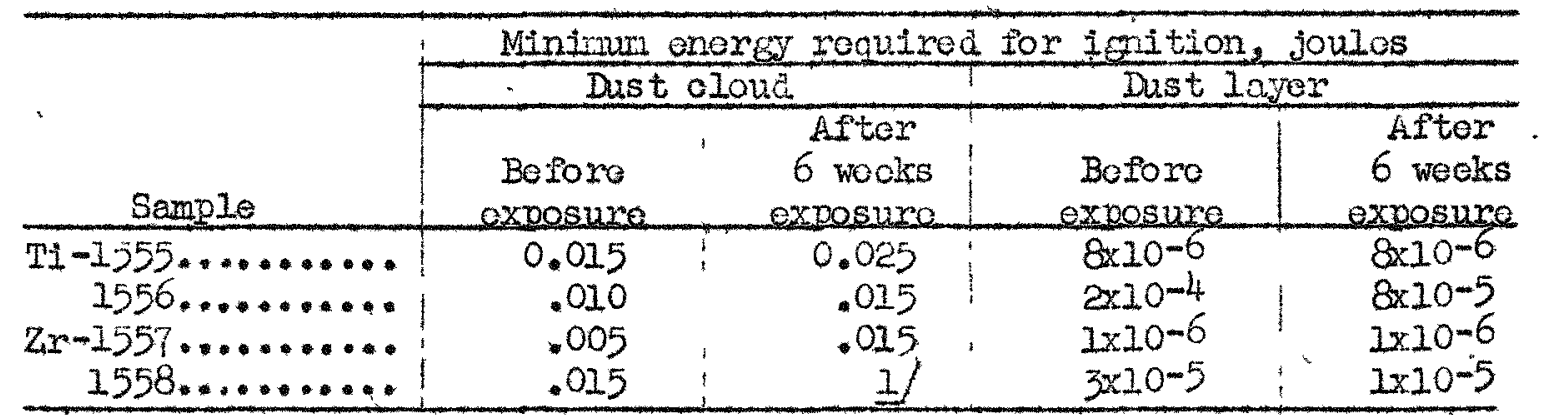

I) No ignitions were obtained at 0.025 jowlo; exrot ilint not detorminod.

The above values show that copper-coatod zirconium (1558) required noro energy for Ignition thon untrected zirconium (1557), whother dispersed in a dust cloud or as a layer. Dust layers of copper-contel titaniuis powdor (1556) also wero nore difficult to ignite thon untreates titaniun (1555); but, when disporsed in the air, tho untreated powder required a slightly higher onergy forrignition, possibly owing to"its soluewhet agslowerated character. On the other hand, a secona copper-coated titaniun powder (1606, table 3 ) was less sonsitive to ignition by sperks in unaispersed form, as woll as in a dust cloud, than tho corresponding untroatod titaniun (No. 1605).

Exposure of the four titaniw powdors in air for several weeks resulted. in an increcse in tho enerey required for ignition of the dust clouis. The enorgy noedod for ignition of cust lajers renainod the saie for the untreated titoniun and zirconiun powders, but the coppex-coatod powiers wore ignited by sonewhet wooker sperks after oxposure.

\section{Minirum Explosive Concontration}

The mininum explosive concentration or lower explosive linit of the powders in air is given in the last colum of table 3. The expeririontal values of this linit are influoncod greatly by tho finenoss of the dust, the unifonity of the dust cloud, the nature of the igniting sourco, and other test conlitions. For this rooson, data detemined by eifferont investigetors are rarely in coiplete agrement. 


\section{Pressures and Rates of Pressure Rise}

The pressure measurements in the 1.23-1iter steel test bomb (fig. 4) were made at concentrations ranging from 0.1 to 4.0 ounces per cubic foot. The test data for 11 samples are given in table 5, and the values for 9 samples are plotted individually on figures 8 to 16. Comparison of the data in the last four columns of table 5, which give the test results by the old method of dust dispersion in the bomb with the results of tests by the new dispersion technique, shows that the latter explosions consistently developed higher pressures and higher rates of pressure rise.

Hor most of the samples plotted on figures 8 to 16 the pressures and the rates developed by the explosions attained maximum values within the concentration range investigated: In general, there was no sharply defined optimum limit at which definito peak values wero roached. As a matter of interest, the stoichiometrio concentrations for the oxides are indicated near the bottom of several figures, although it is not know definitely which oxides are formed (when more than one oxide exists) in the experimental explosions, or whether nitrides also are formed.

In the experiments, the highest pressures were produced by explosions of titanium hydride and the next-highest by zirconium hydride. The highest average rates of pressure rise were produced by zirconium, zirconium hydride, titanium hydride, and uranium hydride. Explosions of several powders developed maximum rates of pressure rise over 10,000 p.s.i. per second.

\section{Ignition by Rlectric Sparks in Inert Atmospheres}

As mentioned above, in the manufacture of highly explosive powders, operations, such as grinding, sieving, and conveying, occasionally are performed in atmospheres having a reduced oxygen content. The data on the ignition temperatures of the samples used for those tests (soe table 2) indicate that dust clouds of some of the metal powders can be ignited at elevated tamperatures in carbon dioxide and that layers of nearly all the powdors can be ignited at olevatod tomperatures in carbon dioxide and in nitrogen. Therefore those gases would ofier Iittle protection against ignition of the powders by hot surfaces or by flames. Howover, in many industrial processes, electric sparks of static or othor origin constitute the prineipal igniting sources.

To study the prevention of ignition by electric sparks, experiments were made with dust clouds of nine powders in various mixtures of air with carbon dioxide, nitrogen, helium, and argon. The clouds were fomed in the presonce of a high-voltage electrical-induction spark in the spark tube shown schomatically in figure 6 , Tho results of the experiments are plottod in figure 17. As illustrated, ignitions by eleotric sparks of dust clouds of the metals and of uranium hydride could be provented most effectivuly in atmos pheres containing mixtures of air and helium. Tho limit mixtures in these atmospheros contained more oxygon than the others. Mixturos of air and nitrogen and air and argon were about oqual in effectiveness, and carbon dioxide was not effective in preventing ignitions. 


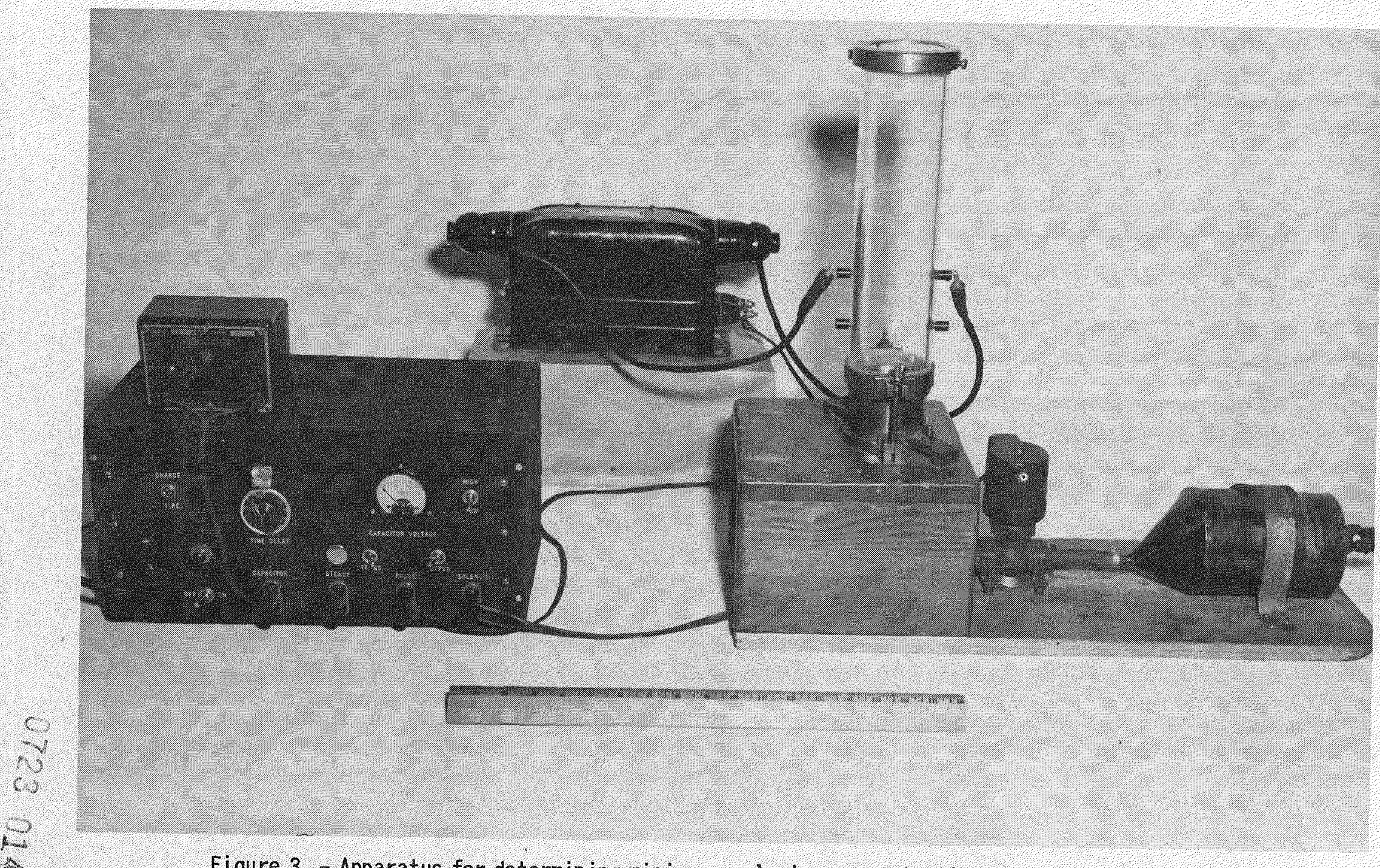

Figure 3. - Apparatus for determin ing minimum explosive concentrations and minimum igniting
energies of dust clouds. 
TABLE 5. Maximum prossures and ratos of pressure rise doveloped in explosions of several powders

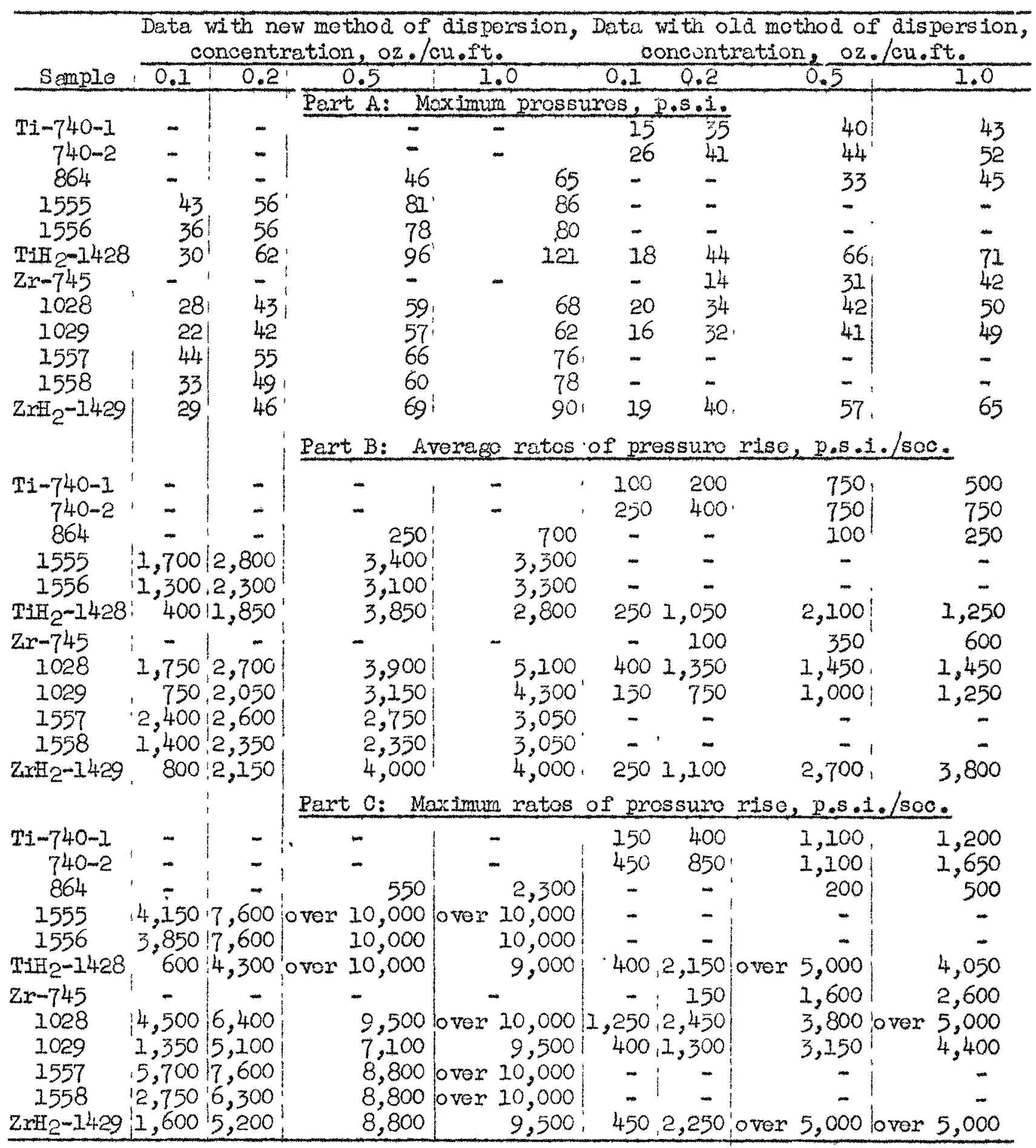

The ineffectiveness of carbon dioxide is not surprising. Past work with other metals, including magnesium and magnesium-aluminum alloys, and the present oxporiments in the fumace have shown that dust clouds of highly reactive 4539 
powders can ignite and explode in carbon dioxide. The greater effectiveness of helium evidentIy is due to its high thermal conductivity. Helium-air mixturos are definitely mora effective in preventing explosions of these five metal powders and uranium hydride than are argon-aix mixtures. Even with helium-air mixtures, however, the oxygen contont of the atmosphere had to be 7 porcont or less to provent ignitions, and it is quite Iikely that in most applications it might be more practical to maintain an atmosphore of pure helium rather than attempt to irepare helium-ait mixturos.

On the other hand, cerbon dioxido-air mixturos woro tho most effoctive portection against ignitions of dust clouds of thorium, zirconium, and titanium hydrides. Tosts also were made in carbon dioxide-ain mixtures with titanium hydride 1428 and zirconium hydxide 1429. The oxygen limits wore detemined to be 13.0 and 8.5 percont, rospectivols. Holium-air and nitrogen-air mixtures wero noarly oqual in effoctiveness. Those findings correspond olosely to tho experimental data for mothane gas, as roportod by Coward and Jones. I6/ The greater offoctivonoss of carbon dioxido is probably due to its highor spocific hoat por unit volume. Holium has high thermal conductivity, but its spociflc heat is loss than half that of carbon dioxido. Tho spocific heat of argon is slightly highor than that of holium, but its thermal conductivity is vory much smaller than that of holium.

\section{RFDUCTION OF FIRE AND EXPLOSION HAZARDS}

The invostigation has shown that the firo and oxplosion hazards incidont to the manufacture and handling oI large quantitios of the subject powdors can be considerable. The hazards are comparablo to, or evon axcsod, those encountored in the manufacture of finoly dividod magnosium or flakod-aluminum powders. It is suggested that laboretorios of plants contumplating production of those powders on an important scalo should consult and follow, insofar as is possiole and pertinent, the recommondations outlined in the codos for the Prevention of Dust Explosions in the Manufacture of Aluminum Bronze Powdor and of Maganesium Powdor or Dust, publishod by the National Fire Proteotion Association, Boston, Mass. Impoxtont rocomendations include eliminating all igition sourcos near dusty processos, roducing tho production of fins dust as much as possible, good housokeoping to provent dissomination of dust in the plant, and the use of inort-bas ataospheres where practicable. Whenover possible at least some, if not all, of tho manufacturing oporations of the more hazardous powders should be performed in atmospheres of helium or argon.

An important safety mocsure against structural damago by oxplosions is the provision of pressure-rolief vents in oquipmont and othor afrected structures. The function of these vents is to reloaso gasos during the initial stages of in explosion, thereby preventing the dovelomont of high prossures.

Recomondations on storing, shipping, oxtinguishing flres, and othor control measures for zirconium powder were publishod in a Safoty Digost by the Nationel Safety Cotmoil, Chicago, I11. Some of this information is also applioable to the preparation and handling of the other powders described in this report. 16) Coward, H. F., and Jones, G. W., Iimits of Inflamability of Gases and Vapors: Bureau of Mines Bull. 279, 1939, flg. 22, p. 54.

4539 $-16-$

Int. - Bu. of Mines, Pgh., Pa. $0723 \cdot 036$ 


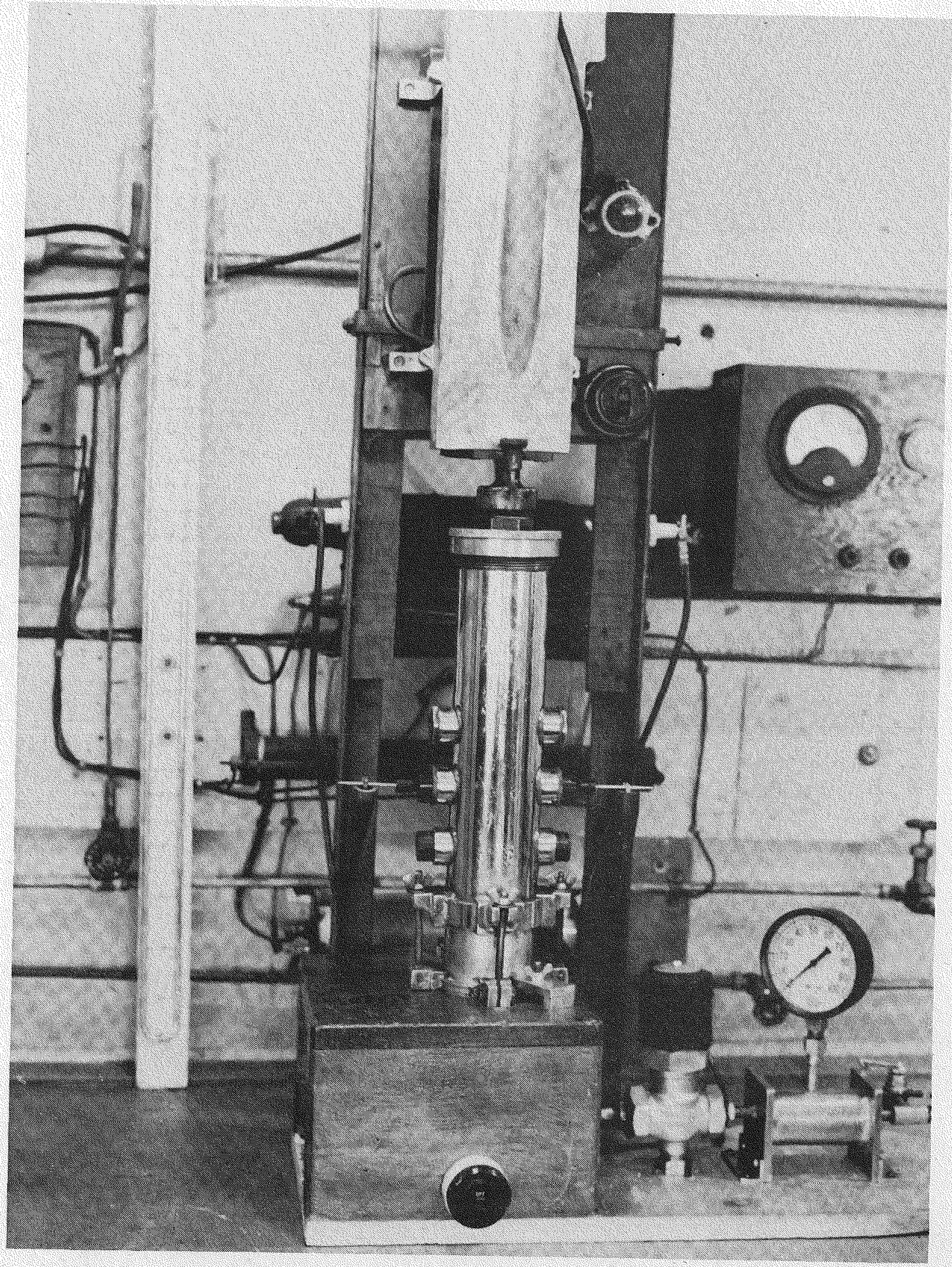

Figure 4. - Apparatus for determining pressures produced by dust explosions.

$$
0723015
$$




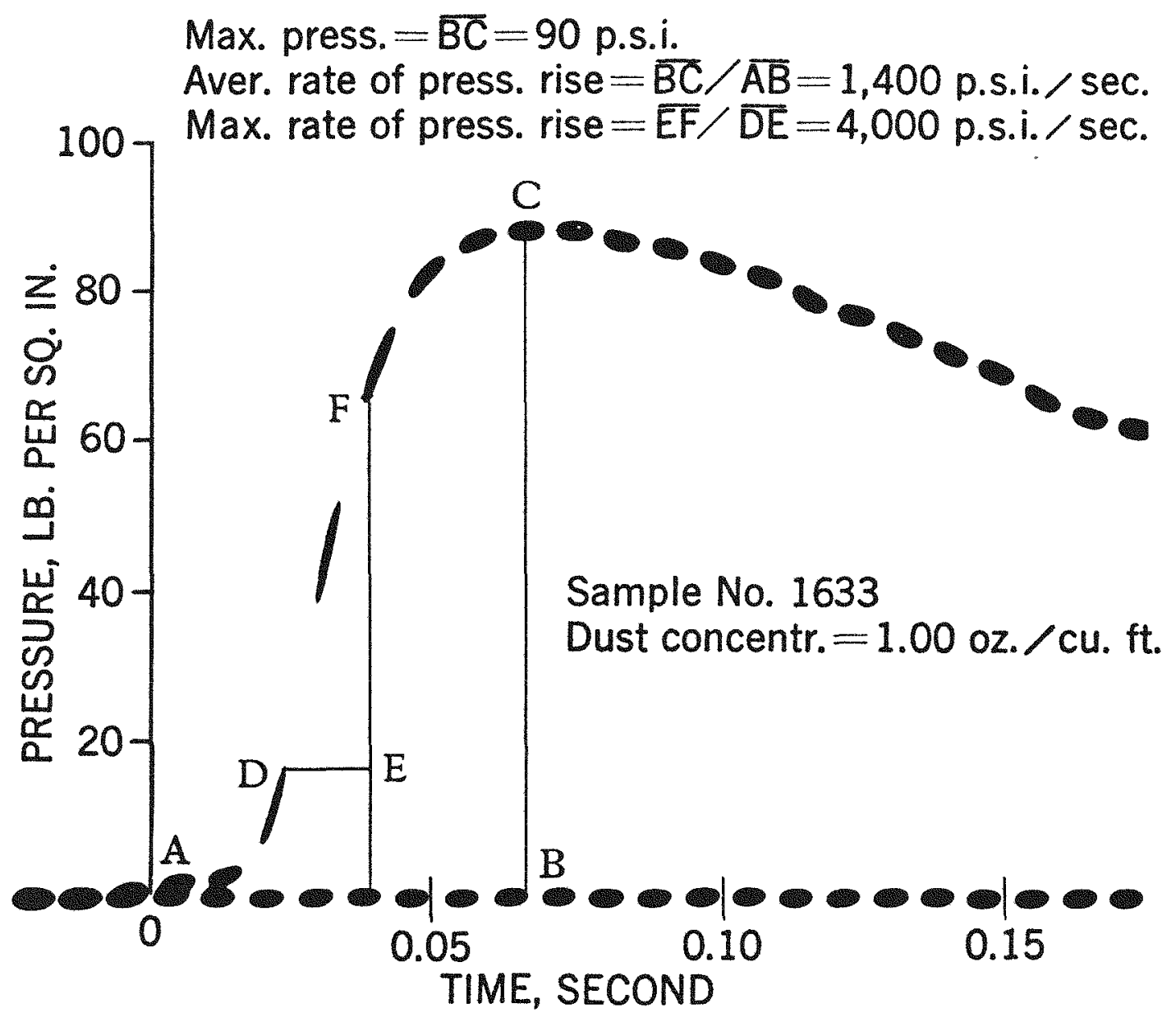

Figure 5. - Pressure-time record of zirconium powder explosion in laboratory test bomb. 


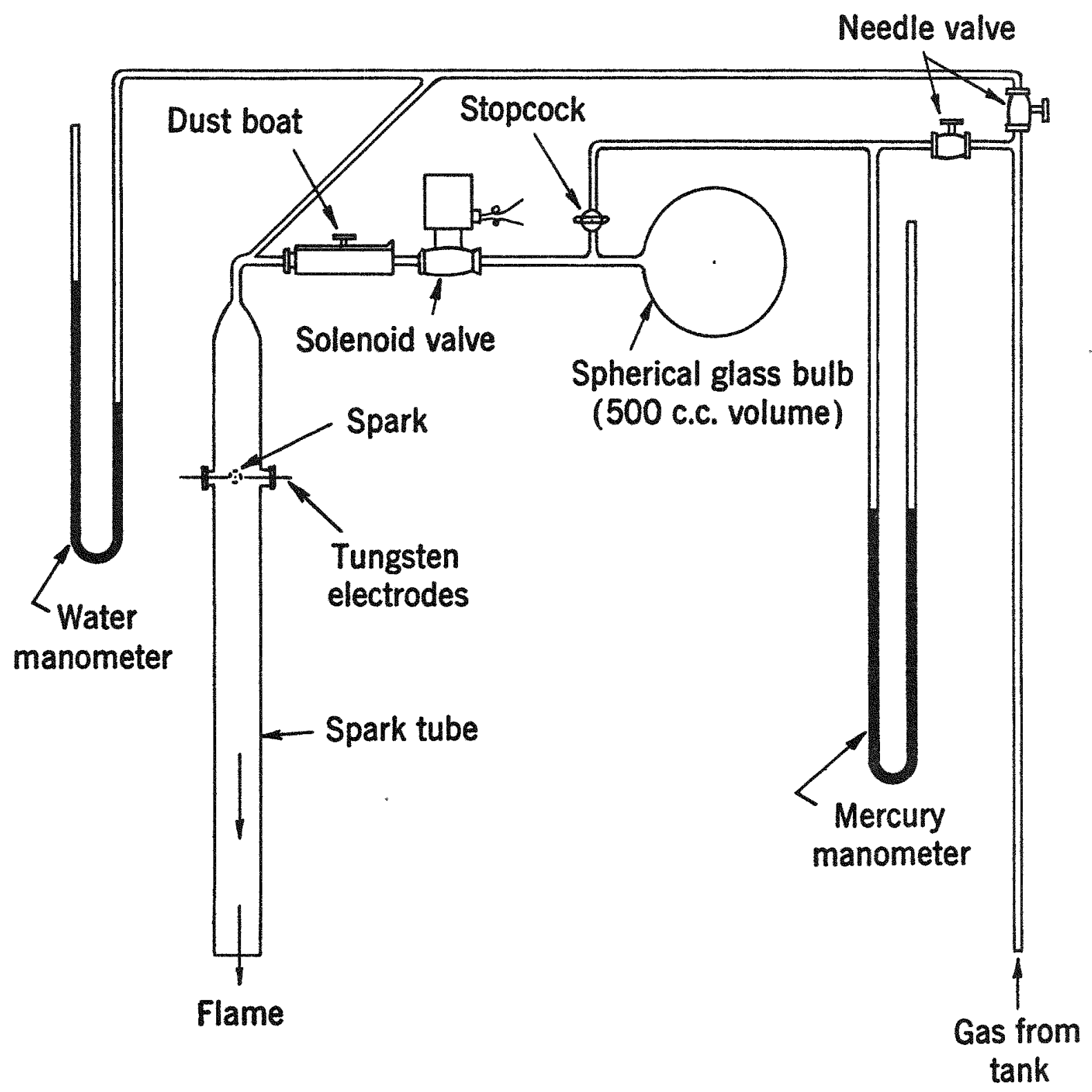

Figure 6. - Spark apparatus for testing dust flammability in various gases.

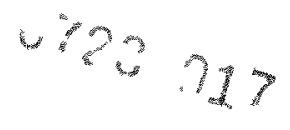




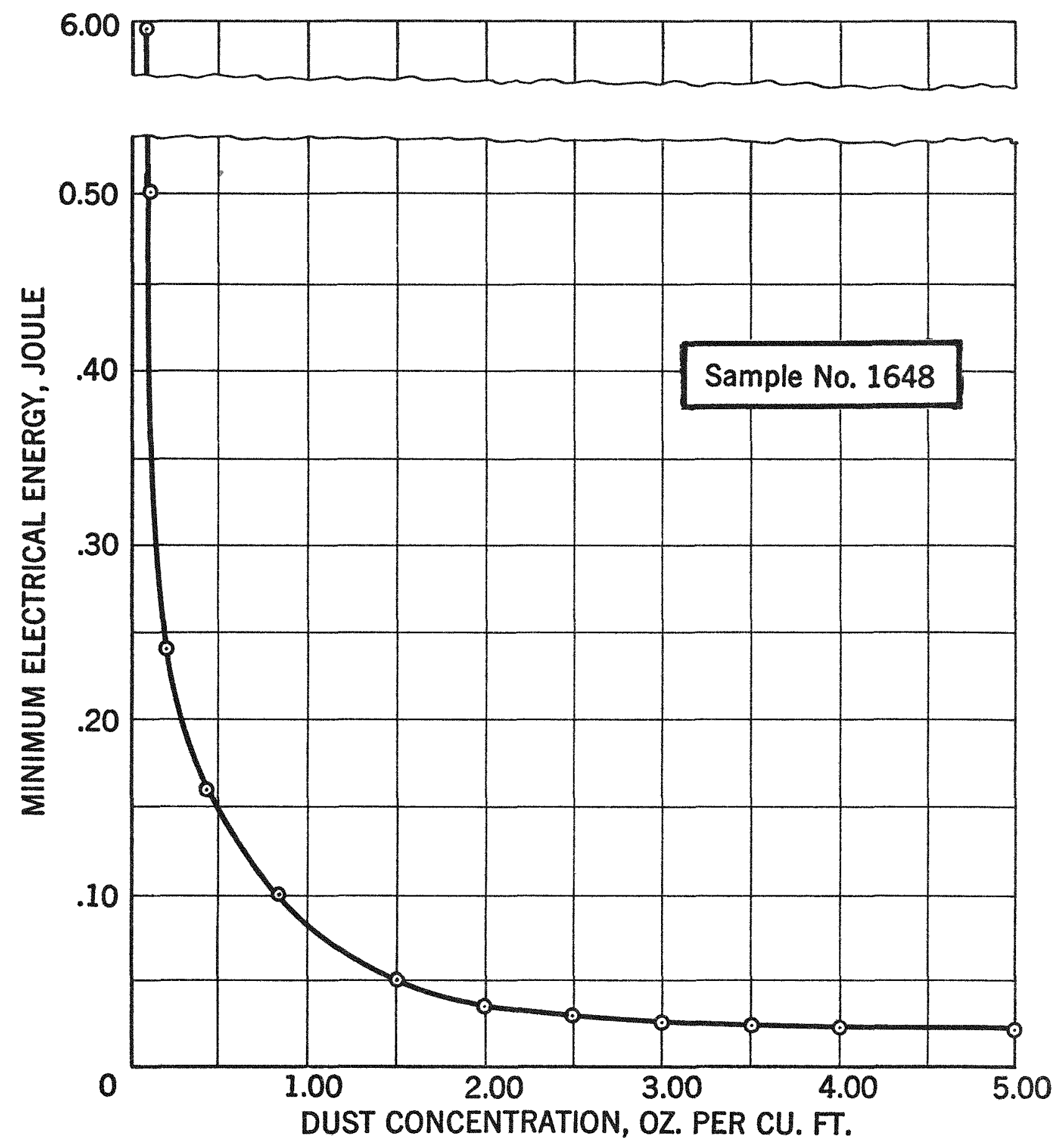

Figure 7. - Minimum el ectrical energy required to ignite dust clouds of titan ium. 0723022 


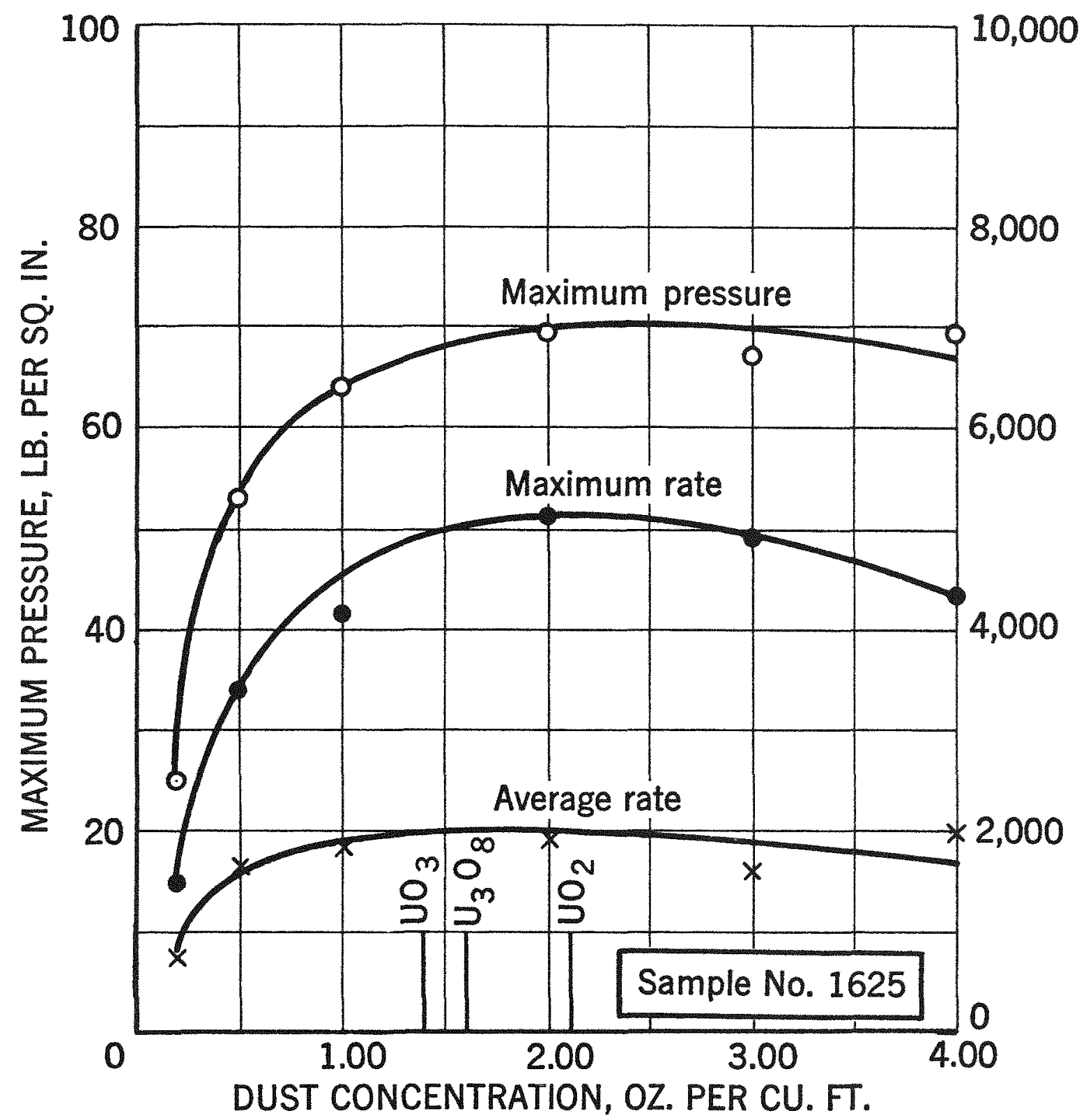

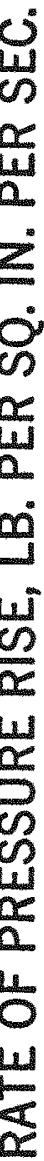

Figure 8. - Maximum pressure and rates of pressure rise developed by explosions of urani um.

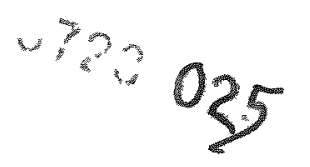




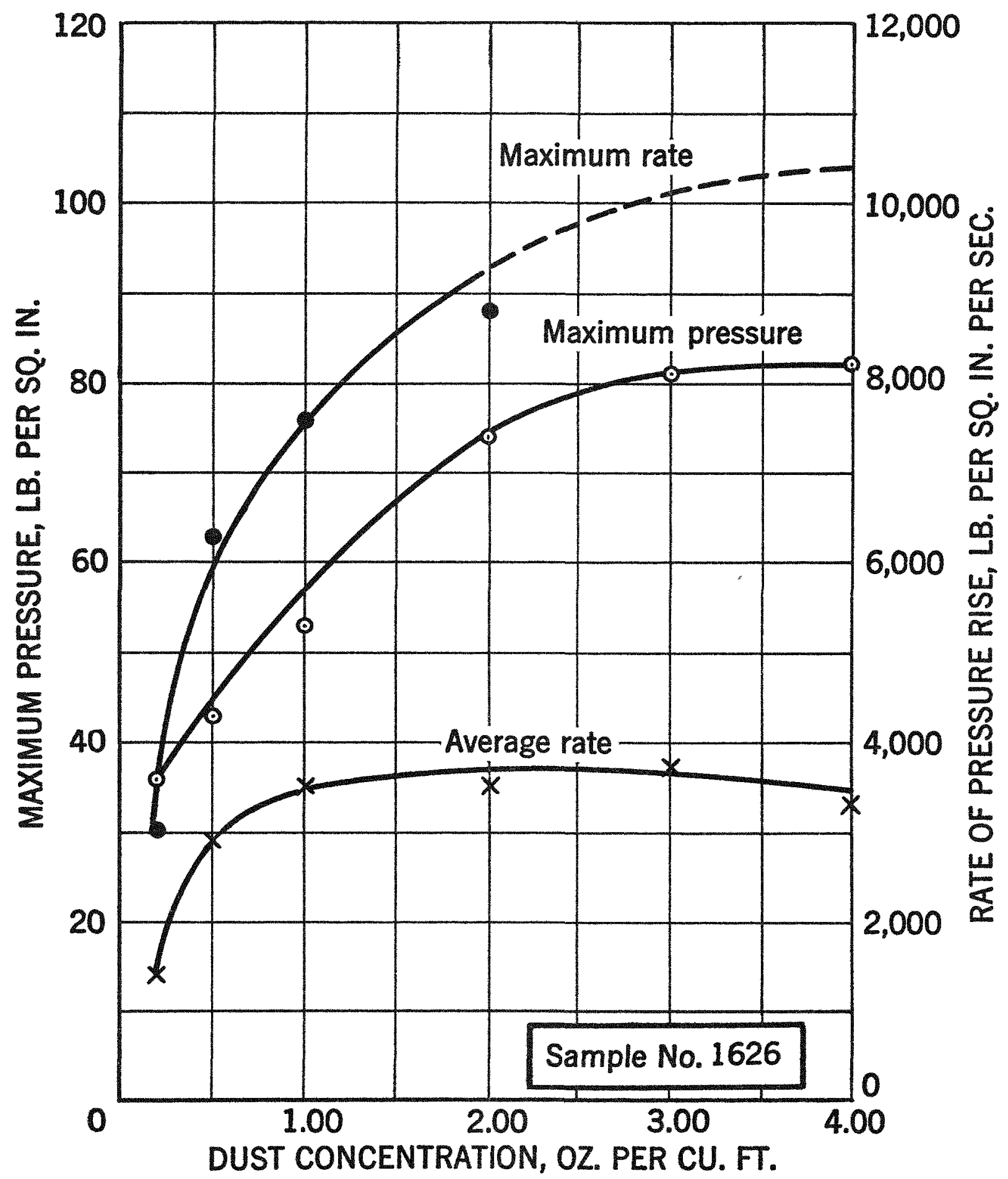

Figure 9. - Maximum pressure and rates of pressure rise developed by explosions of uran i um hydride. 


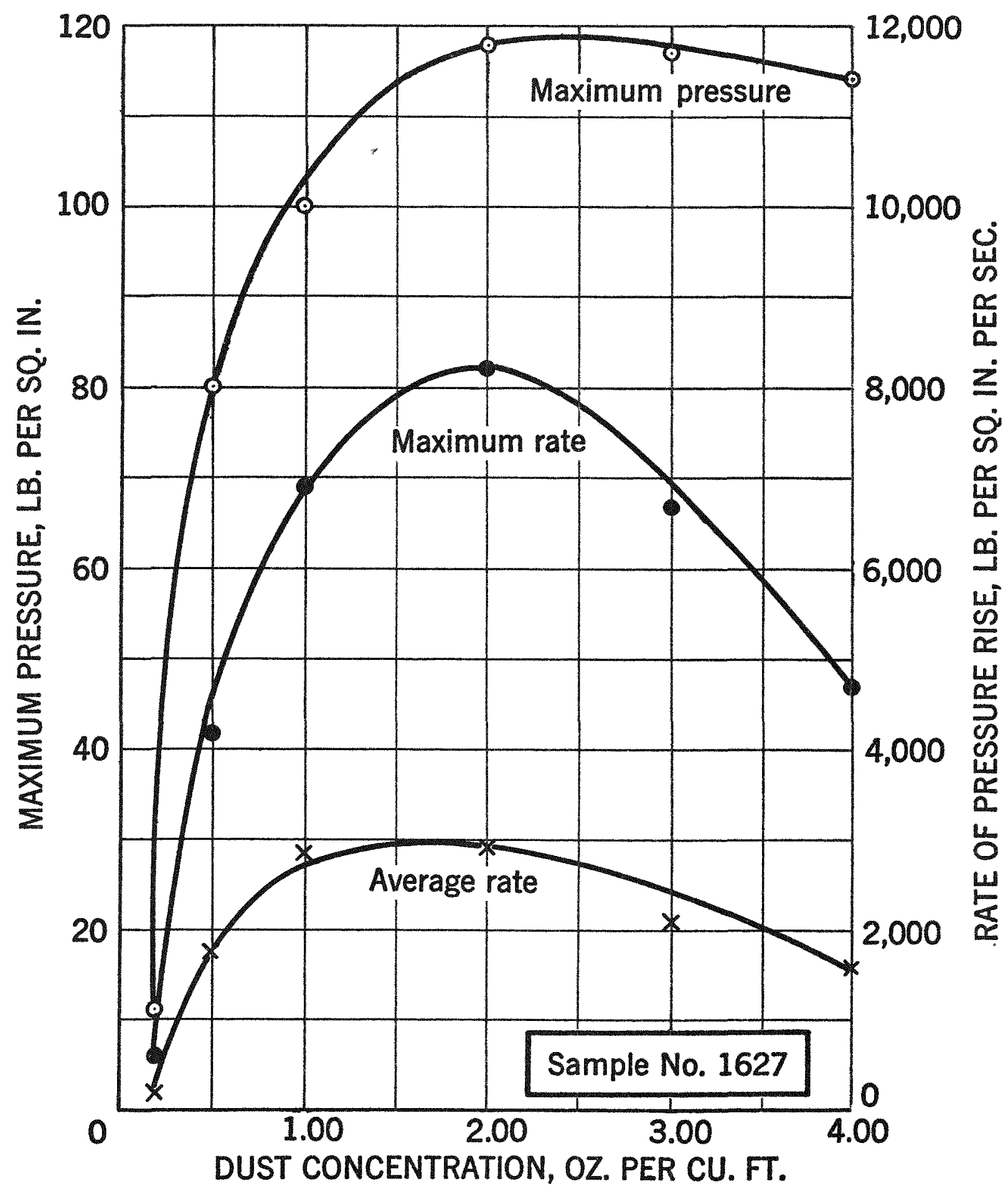

Figure 10. - Maximum pressure and rates of pressure rise developed by explosions of zi rconi um hydride. 


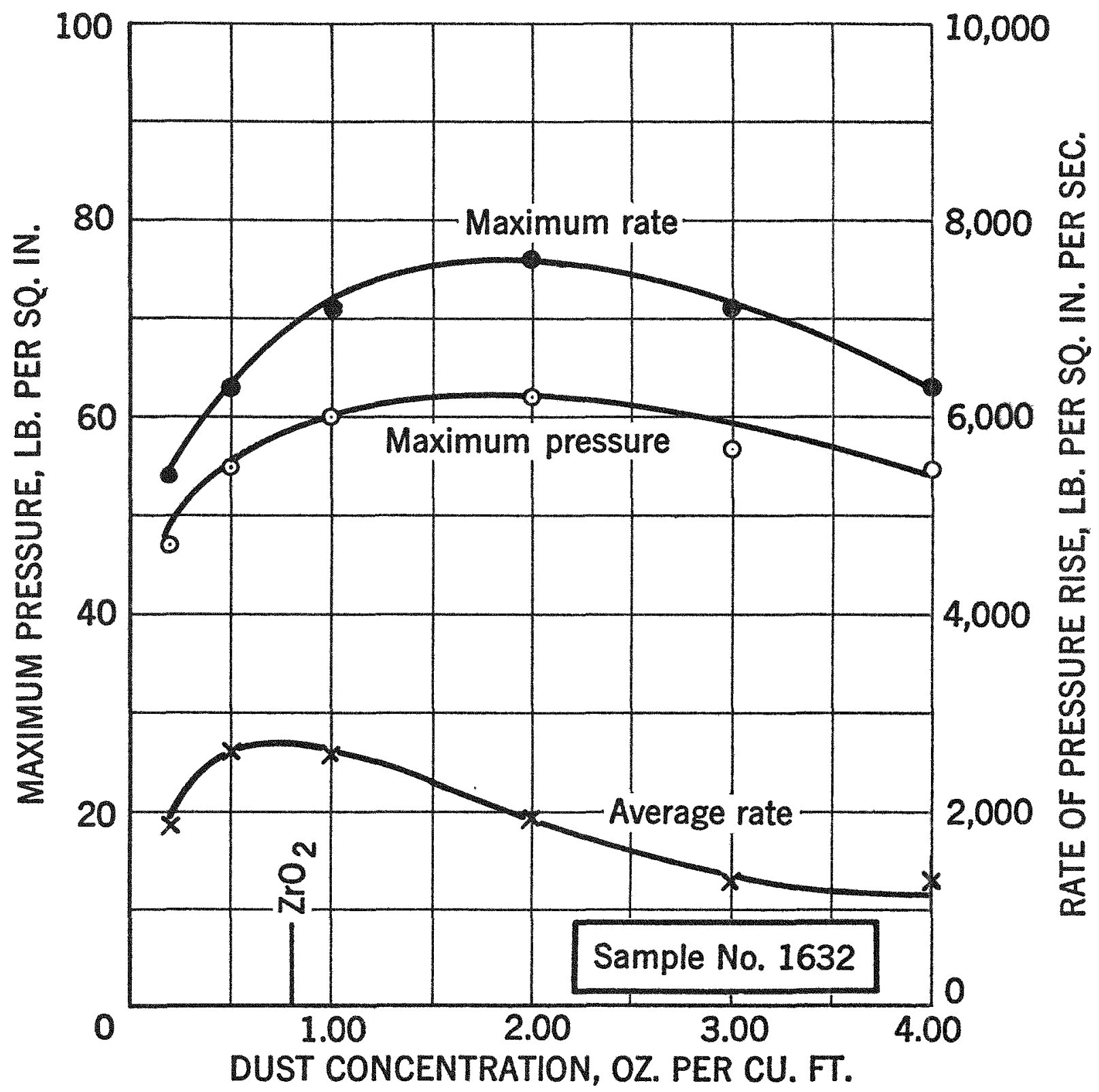

Figure 11. - Maximum pressure and rates of pressure rise developed by explosions of fine zirconi um.

$$
\text { प? } 028
$$




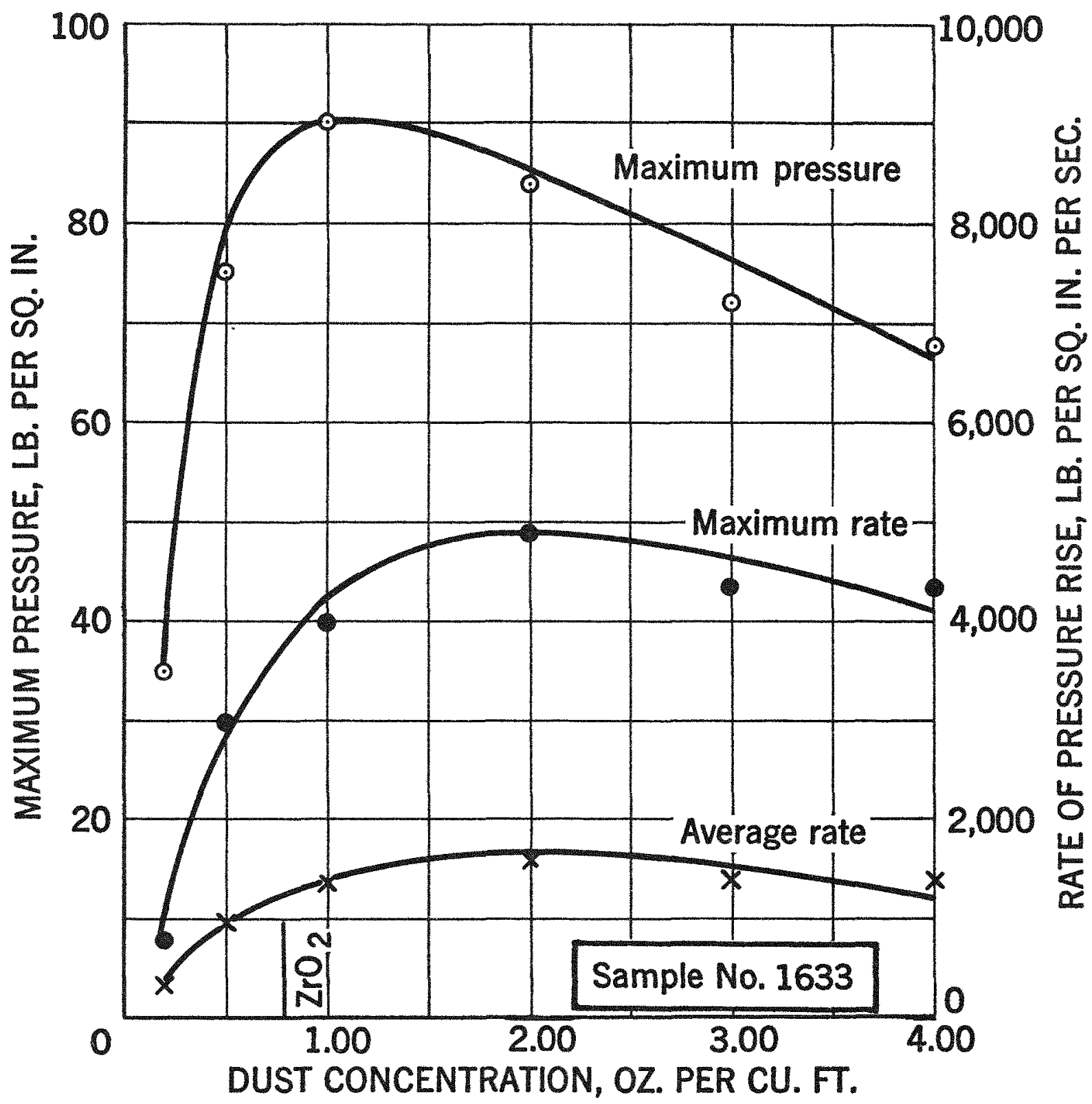

Figure 12. - Maximum pressure and rates of pressure rise developed by explosions of zirconium.

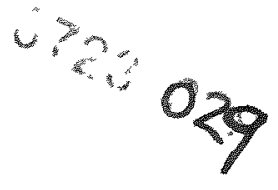




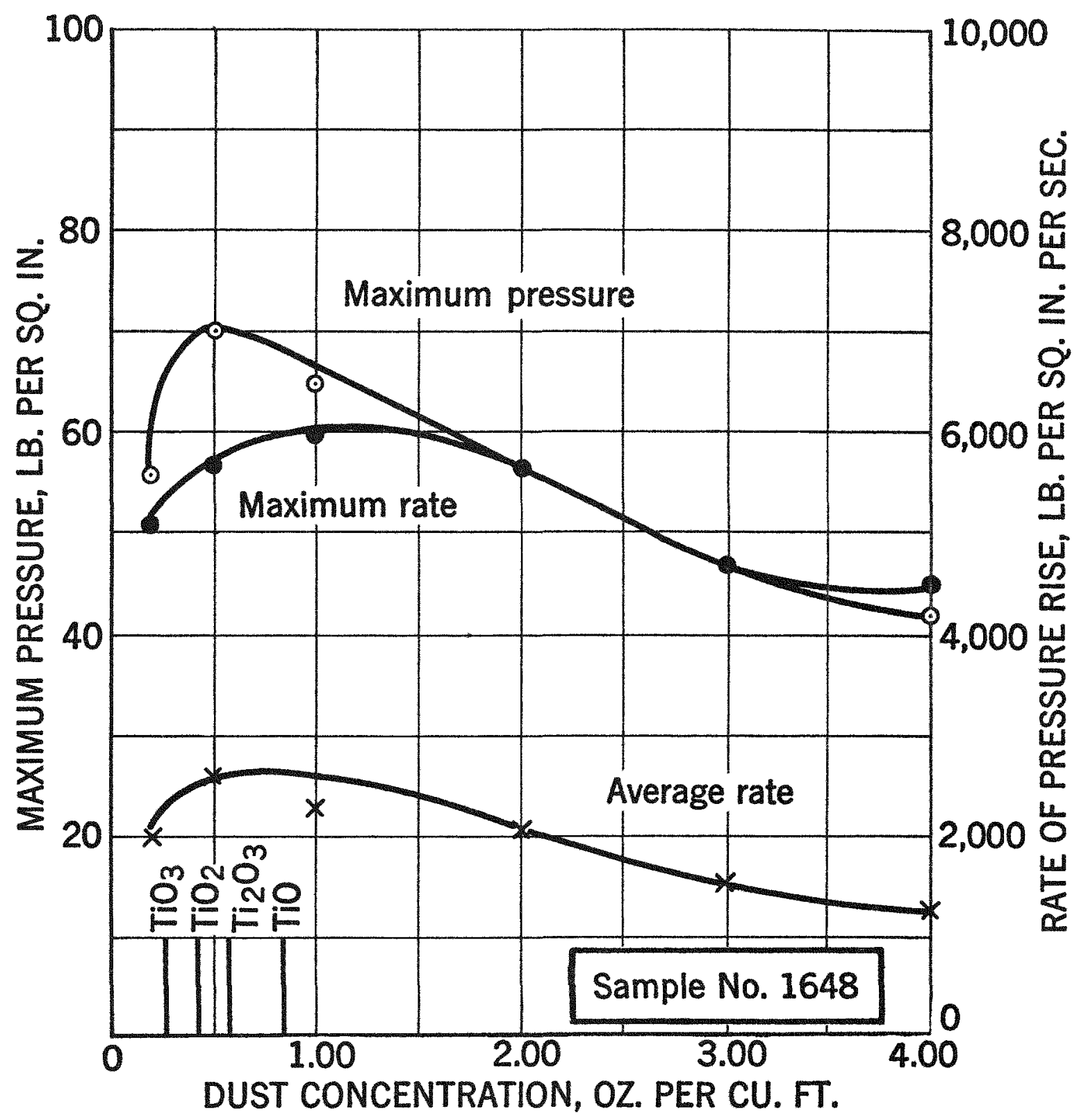

Figure 13. - Maximum pressure and rates of pressure rise developed by explosions of ti tanium.

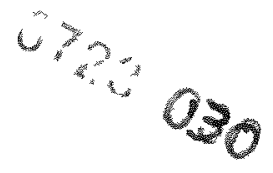




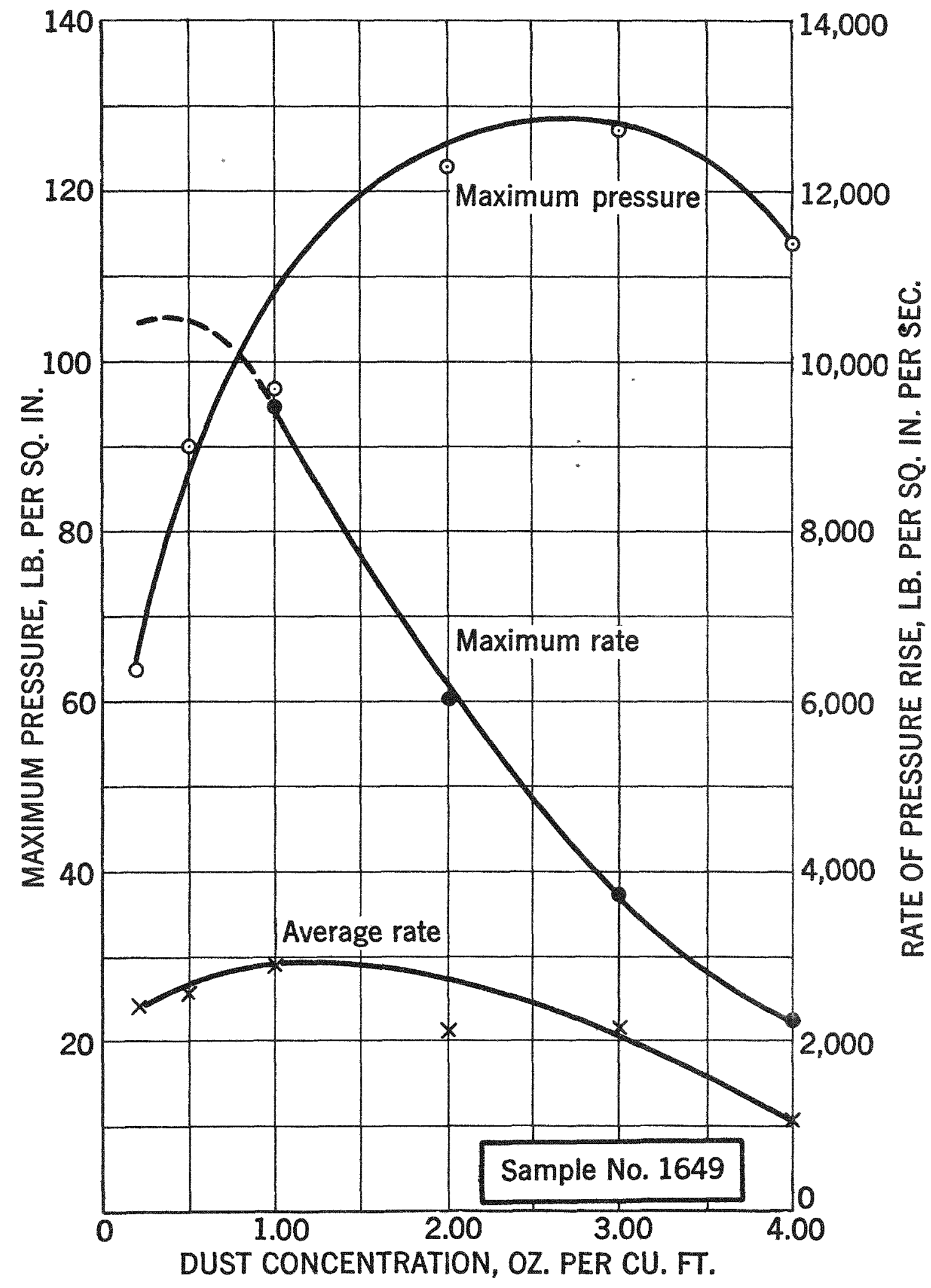

Figure 14. - Maximum pressure and rates of pressure rise developed by explosions of titanium hydride. 


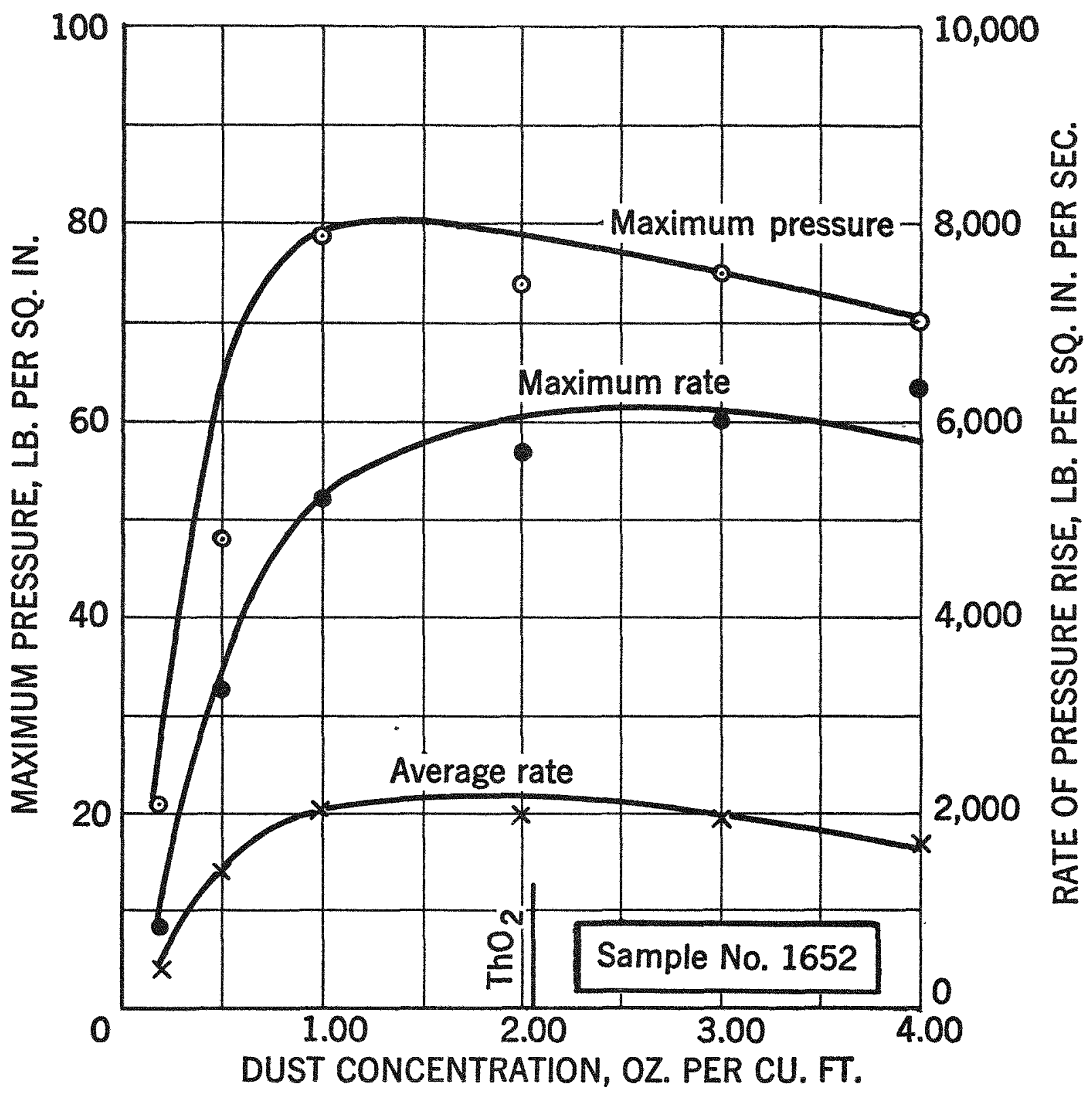

Figure 15. - Maximum pressure and rates of pressure rise developed by explosions of thorium.

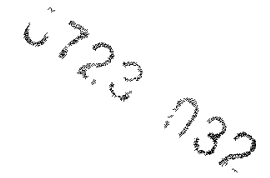




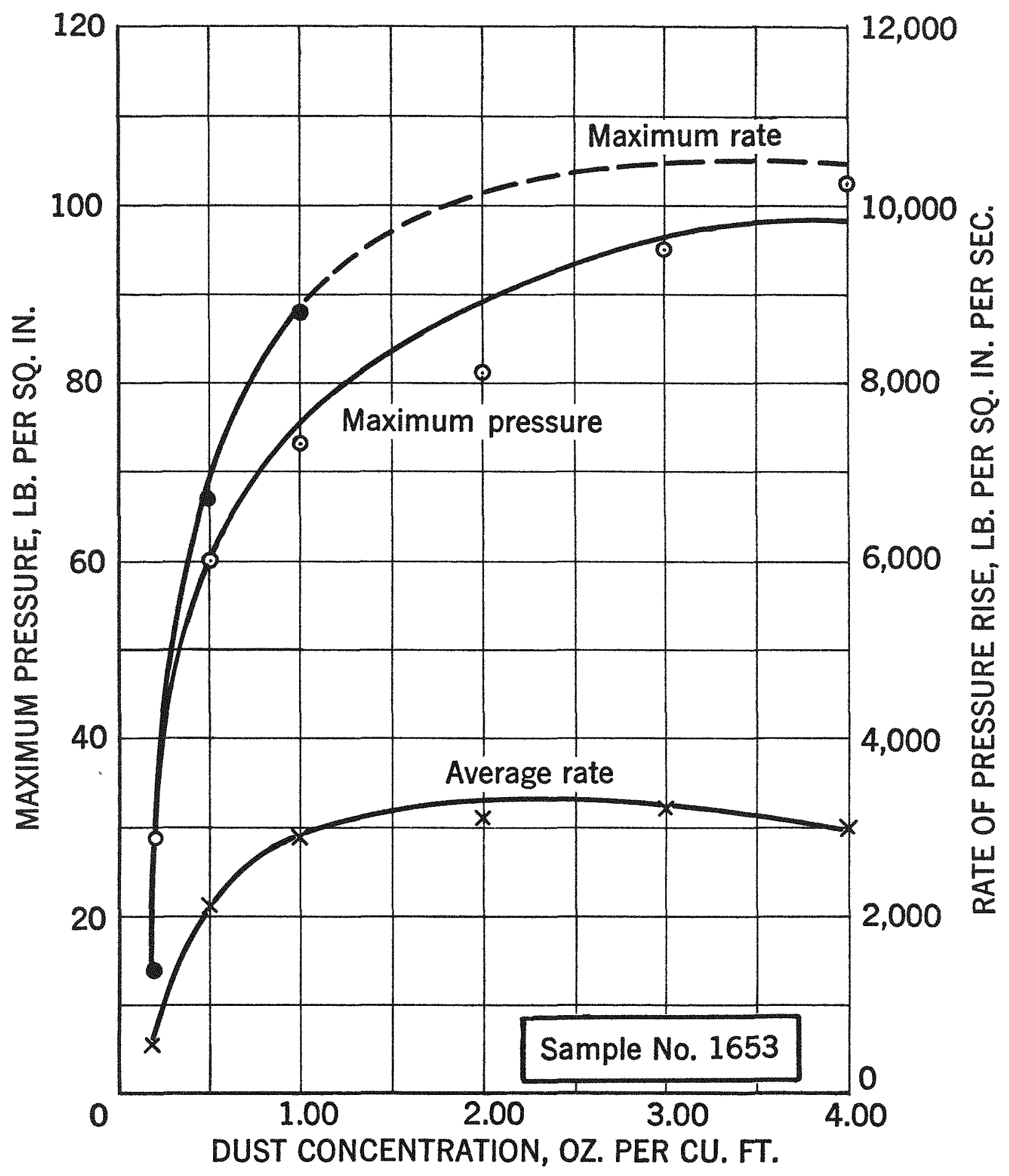

Figure 16. - Maximum pressure and rates of pressure rise developed by explosions of thorium hydride.

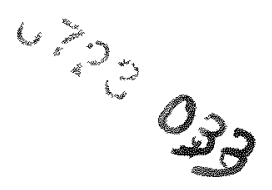


